\title{
Imagery of ad-venture: Understanding entrepreneurial identity through metaphor and
}

drawing

\begin{abstract}
We examine how visual metaphor can reveal the tacit assumptions that entrepreneurs use to make sense of their identities. While metaphor is often equated with linguistic metaphor, here we argue that metaphors created through the modality of drawing ean offerafford a mere nuanced insight into the continual work of creating and recreating a sense of entrepreneurial self. how entrepreneurs make sense of their entrepreneurial identity. From an analysis of the images created-drawn by entrepreneurs and accompanying interviews, metaphors emerge that appear to carry more ambiguity are much more complex, nuanced and messy than their linguistic equivalents. The images allow entrepreneurs to isolate and fix salient meaning about 'being in business', theybut refrain from simplifying what remains a complex and at times contradictory and paradoxical experience.
\end{abstract}

Keywords: visual metaphor, entrepreneurial identity, drawing methodology 


\section{Executive Summary}

In this paper we seek to understand how entrepreneurs use metaphor to make sense of their entrepreneurial experience. Existing literature has establishedacknowledges how that metaphors play an integral role in how entrepreneurs negotiate the uncertainty of their environment and create meaning for themselves and others. These studies, though, tend to concentrate on the Existing research has identified the metaphors-metaphors commonly used by others used by others (e.g. the media, academics, general public) to describe andte understand the entrepreneurship process, often framing the entrepreneur as some form of rulebreaking, individualist on a heroic quest to realize business opportunities in ways few others could..ideal. As yet little attention has been directed towards the metaphors that entrepreneurs themselves use to make sense of their entrepreneurial identity.--Our study is of entrepreneurs' own use of metaphor. A grounding concern was the ubiquity of standard metaphors that might $\underline{\text { then be used entrepreneurs with little thought for whether they really evoked the often }}$ uncertain and elusive nature of entrepreneurial experience. The metaphor associated with individualism and heroic struggle are so common they can conceal as much meaning as they reveals. To account for this we asked entrepreneurs to use drawings. WWhile metaphors are often equated with linguistic metaphors, we argue that-metaphor is not necessarily grounded in words. Rather it is, but argue in this paper that what constitutes metaphor are not particular words or expressions but rather-the mapping of meaning from $m$ afamiliar experience to ato less familiar experiences, and whilst words. Words are wonderful at embodying such a move, but Metaphors can therefore be elicited inthere are ether-modalities other ether than speech and writing, and drawing is one. Moreover, the more a linguistic metaphor gets used unreflectively the less work it does in helping us understand the strange, uncertain and elusive experiences that can characterize entrepreneurial practice. If the prevailing metaphors associated with heroic individualism are not longer adequate to understand the phenomenon 
of entrepreneurial identity creation, then are there alternatives? which Other words might work, but offers the oppertunity to move beyond an unreflective use of common linguistic metaphors of entrepreneurship that can potentially conceal as much as they reveal. Inour study also looks beyond words order to elicit non verbal metaphors of entrepreneurial identity by, we introduceusing drawing, as a methodology into the field of entrepreneurship studies. Our sample of 20 high-growth entrepreneurs were asked to draw a visual image of their business venture and then interviewed about the subsequent images. Whilst in some What emerges is a sense of entrepreneurial identity associated with undergoing journeys, with transformation and growth, and with nurturing communities. These qualities can be in tension $\underline{\text { as much as harmony, and yet somehow can co-exist, and can come to the fore or recede over }}$ $\underline{\text { time. From this we argue that forming of entreprenerurial identity is neither singular nor }}$ fixed. And in terms of its content, in our sample at least, it is not at all individualistic in nature. Indeed, we conclude from analysing the drawings that acknowledging and working with identity fluidity is a defining capacity of being entrepreneurial.

\section{Introduction}

Metaphors ground the creation of entrepreneurial identities by bringing concepts from different, better-known domains into conversation with the ambiguous experience of being an entrepreneur (Dodd, 2002; Perren and Adkin, 1997). Existing studies have tended to take a macro focus, combining metaphors used to depict entrepreneurs from a range of sources (including media journalists, lay people, entrepreneurial support agencies) (Dodd and de Koning, 2015; Koiranen, 1995; Nicholson and Anderson, 2005). These studies show entrepreneurship being collectively and culturally constituted through metaphors that portray the entrepreneur 'within a heroic mould (warrior, superman, explorer, battler)' where 'mythical, magical and supernatural imagery is evoked: wolfish charmers, wizards and 
supernatural gurus' (Down and Warren, 2008, p. 7). Metaphors influence the connections we make but also the connections we don't make ${ }_{2}$ and by emphasising certain interpretations, dominant metaphors tends to force others into the background resulting in partial understandings (Kemp, 2016; Näslund and Pemer, 2012). Existing work on entrepreneurial identity has shown that there are potentially multiple salient founder identities (Cardon et al, 2009; Powell and Baker, 2014; Mathias and Williams, 2017). For example, Fauchart and Gruber (2011) identify founders who aligned with the prototypical 'heroic' entrepreneurial identity focused on economic self-interest (what they term the 'darwinian' founder identity), but they also found entrepreneur's identities that werebeing framed around supporting and being supported by a particular community (the communitarian) and advancing a particular cause for the benefit of society (the missionary). Therefore, while some entrepreneurs may identify with common heroic metaphors comparingef entrepreneurship to rule-breaking and

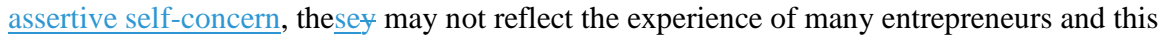
dominant perspective may be limiting insight into the multifaceted nature of entrepreneurial identity (Dodd, 2002; Morgan, 2006). Moreover, such identities need not be mutually exclusive. Over time and within a venture different identities can be experienced, either serially as founders give way to others during the growth of the enterprise (Powell and Baker, 2014) or as a multiplicity, for example in relation to emergence of new market categories

\section{(Navis and Glynn, 2010)}

In this paper we examine the metaphors entrepreneurs themselves use to make sense of their experiences of being in business. It is often assumed metaphors are primarily verbal without due consideration being given to the possibility of accessing metaphors in different modalities (Forceville and Urios-Aparisi, 2009). Here we argue that visual metaphors, especially through the modality of drawing, have the quality of being thoughtfully created in a way that is direct and singularpersonal, bringing out a grounding and basic sense of business 
experience, without the resulting meaning ever being considered definitive or complete. We argue these drawings and the accompanying discussions with the entrepreneurs about the images, offer a unique insight into the metaphors entrepreneurs use to interpret and understand their world and make sense of their entrepreneurial identity (Hoang and Gimeno, 2010, Philips et al, 2013). As the backdrop for our investigation, we draw on the theoretical perspective that metaphor is 'not a figure of speech, but a model of thought' (Lakoff 1993, p. 210) as what constitute metaphors are not any particular words or expressions but rather a mapping across conceptual domains, from the familiar source domain to the less familiar target domain. We propose researchers should think aboutunderstand metaphors independently from a specific modality, instead seeing metaphor as not just a matter of language words but of active thought, thinking, understanding and communication. This offers the opportunity to move beyond an unreflective use of preponderant linguistic metaphors of entrepreneurial identity that-can potentially conceal as much as they reveal about entrepreneurship (Morgan, 2006).

We use a sample of twenty entrepreneurs, whose ventures were identified as 'high growth', taking part in a development program at a leading UK University. We focus on socalled 'high growth' firms, those assumed to be the epitome of what entrepreneurial businesses should be both in academic literature and government policy (Gundry and Welsch, 2001). The entrepreneurs were asked to draw an image exemplifying or evoking their business venture and were subsequently interviewed about their images. The aim was to allow a more 'nuanced depiction of lived realities, while simultaneously empowering the research participants and placing the agency literally in their own hands' (Literat, 2013, p. 12). The findings show little evidence of the 'entrepreneur as hero' metaphor, or in Fauchart and Gruber's (2011) terms the 'darwinian' founder identity. Instead the metaphors elicited reflected the entrepreneurs' sense of social embeddedness and their ventures as cooperative 
endeavors, evoking 'communitarian' or 'missionary' identities (Fauchart and Gruber, 2011). The valence of the images (whether the images had primarily positive or negative connotations) was largely positive, which we argue is-evokes an on-going attempt by the entrepreneurs to secure positive meanings in the face of potential negative consequences of their entrepreneurial activities and protect themselves from identity threat (Ashforth and Kreiner, 1999). -Some of the metaphors did relate to existing linguistic metaphors of entrepreneurship including the entrepreneur as a traveler on a journey (Dodd, 2002; Maclean et al, 2015), metaphors relating to family and parenting (Cardon et al, 2005) and the biological growth metaphor (Aldrich and Martinez, 2001; Clarke et al, 2014). However these 'typical' metaphors as conveyed through drawing were much more complex, nuanced and messy than their linguistic equivalents; the images isolate salient and basic meaning but refrain from simplifying what remains an elusive complex and at times contradictory and paradoxical experience. Drawings reveal the multiple nature of entrepreneurial identity, both in terms of their emphasis and particular quality, and their mobility over time.

Our study makes two contributions. First we make a distinctive and substantive methodological contribution through the introduction of drawing explicitly as a methodology into the field of entrepreneurship. With a few notable exceptions (e.g. Barner, 2008; Vince and Broussine, 1996; Ward and Shortt, 2013; Zuboff, 1988) found primarily in the field of organization studies, the use of drawing methods in business and management research remains rare (Meyer, 1991). Existing work tends to begin from a psychoanalytic perspective where drawing is undertaken as a means to uncover 'unconscious' emotions underlying behaviours (Vince and Broussine 1996). In this study we make a number of modifications to the drawing methodology to enable us to reveal tacit metaphors of entrepreneurial identities. The approach described here did not use the collective construal approach - which involves participants collectively discussing and creating meaning about the images - and instead we 
focus solely on entrepreneurs individual insights into the drawings. We also had a period of time between the creation of the drawings and the verbal discussion of the drawings to help avoid verbal overshadowing of visual insights (Kantrowitz, 2012). Finally we also offer a more fine-grained insight into the relationship between the images and the textual description building on protocols of analysis from the social semiotics literature (Kress and van Leeuwen, 2006). Previously drawing-based research has tended use images as a means to elicit the textual transcript, whereupon the images 'disappear from the analytical frame' (Vince and Warren, 2012, p. 288). The process described here not only offers insight into how drawing as a methodology can be adapted to suit the needs of different research aims but also provides a strong analytical process to allow future research to develop understandings of the insights offered by both visual and verbal modes of meaning-making.

Secondly our study is the first to provide both visual and verbal sources of evidence of the metaphors used by entrepreneurs to construct their identities and provides a unique insight into how entrepreneurs make sense of being in business, offering implications for the practice and theory of entrepreneurship. Due to their different affordances and constraints, the visual and verbal modalities fulfil different but complementary roles in terms of conveying meaning, supplementing, and integrating one other (Kress and van Leeuwen 2001; Lemke, 2004). In terms of practice we argue the opportunity to deliberately and intentionally visually create, and subsequently verbally reflect on metaphors of their experience allowed the entrepreneurs to shed common linguistic metaphors of entrepreneurship, and surface rather than suppress, the rich, nuanced and messy nature of entrepreneurial experience. The drawings gave them space to think about and 'stay' with these often paradoxical experiences rather than aiming to resolve or rationalise the tensions inherent in what it means to be an entrepreneur, opening up the potential to give meaning to these apparent contradictions (Lewis, 2000). Theoretically our study illustrates the risks in confining entrepreneurial identity to any singular or dominant 
metaphor, indeed it upends this tendency by arguing what isto have an entrepreneurial identity is precisely the experience of living with and absorbing complexity, contradiction and ambiguity. Previous identity research has also highlighted that individual entrepreneurs may assume many distinct role identities, but they tend to assume that one identity will be more salient at any one time (e.g. Mathias and Williams, 2017). The findings here reveal a more complex relationship where many, often contradictory, entrepreneurial identities are concurrently activated (e.g. entrepreneur as provider while also being dependent) (Cardon et al, 2009). Entrepreneurship should be understood through a kaleidoscope of metaphors where the insights of one metaphor can help us overcome the limitations of another. Working with many competing metaphoric understandings and creating a mosaic of insights to explore the intricacies of entrepreneurial experience allows us to mobilise the true power of metaphor (Morgan, 2006).

\section{Theoretical Background}

\subsection{Metaphor and entrepreneurial identity}

To approach any awareness of complex, uncertain and unfamiliar phenomena, we often draw upon more accessible and familiar areas of experience. In many cases, we convey what would otherwise be difficult to articulate ideas using metaphors referring to more common perceptions and conceptions (Cornelissen, 2005). These ideas are elaborated in the seminal work of Lakoff and Johnson $(1980,1999)$ who argue human sensemaking is inherently more figurative than it is literal. They suggest metaphors are fundamental and omnipresent in our thinking and understanding and 'which metaphors we have and what they mean depend on the nature of our bodies, our interactions in the physical environment, and our social and cultural practices' (Lakoff and Johnson 1980, p. 247). The pervasive use of metaphor indicates 'the systematic and frequently visible tips of lots of icebergs of massive underlying conceptual structures of metaphor in thought' which we use to make sense of our 
own actions and those of others (Steen, 2014, p. 119). The use of metaphor implies a way of thinking and seeing that pervades how we understand our world (Morgan, 2006). Metaphors transcend language and operate at structuring levels of action and thinking by linking two domains: the 'source' domain and the 'target' domain. The 'source' domain is the domain from which we draw metaphorical expressions typically based on concrete, embodied experiences. The 'target' domain tends to have a somewhat elusive quality (for example the creation of a new venture), and these take their structure from more familiar source domains (entrepreneurship as fight or war) through metaphorical links. We develop understandings of the complex and vague through the filter of more tangible experiences. In fact, 'as soon as one gets away from concrete physical experience and starts talking about abstractions or emotions, metaphorical understanding is the norm' (Lakoff, 1993, p. 205).

Perhaps more than other business figures, entrepreneurs act and think in ways that bridge target and source domains; they use metaphor to compress the often elusive prospect of venture-forming into familiar categories or scenes allowing them to make sense of their entrepreneurial experience and create an entrepreneurial identity (Maclean et al, 2015). Entrepreneurs' use of metaphors, far from being simply a figure of speech or embellishment of spoken or written language, function as organizing principles of their experience. Metaphors 'establish images, names and an understanding of how things fit together ... [they] articulate what is important and unimportant' (Hill and Levenhagen 1995, p. 1057). But just as metaphors open up new domains of insight they also direct attention away from other ways of seeing and thinking. As Morgan (2006, p. 5) puts it 'metaphor is inherently paradoxical. It can create powerful insights that also become distortions, as the way of seeing created through a metaphor becomes a way of not seeing'. Metaphors generate valuable insights and can be extremely persuasive, but this persuasiveness can work to limit our understandings, through blinding and blocking our ability to gain another view. By 
emphasising certain interpretations, metaphor tends to force others into the background (Kemp, 2016; Lundmark and Westelius, 2014). This partiality is inherent to metaphorical understanding - they introduce but also obscure the complex and polyphonous nature of experience (Morgan, 2006; Näslund and Pemer, 2012).).

Take the prevalent metaphor of the entrepreneur as a heroic, solitary adventurer (Pitt, 1998), whose productive activity is governed by a value-neutral, profit-seeking logic (Smith, 1999). Does this emphasis on fostering accumulation and reach, the creation of personal wealth, also conceal meaning? The underlying idea of entrepreneurship as an individualised and isolated activity is increasingly coming under scrutiny (Dodd and Anderson, 2007; Ogbor, 2000). As Fauchart and Gruber (2011) show that while some founder identities are primarily fixed around creating economic profit, other founder identities are rooted in providing support for their community and advancing a particular societal cause. Far from being isolated, private creations, entrepreneurs rely on previous working relationships, voluntary connections, kinship and community ties as a means to access appropriate resources to create and sustain their venture (Greve and Salaff, 2003; Hoang and Antonic, 2003). As

Korsgaard and Anderson (2011) show the creation of economic wealth is only one measure of entrepreneurial contribution, and metaphors that make 'visible' economic value can make 'invisible' the many other dimensions involved in entrepreneurship (social, personal, spatial, environmental) (Anderson and Smith, 2007; Clarke et al, 2014). The vast majority of studies examining metaphors of entrepreneurship aim to capture the embedded entrepreneurial narratives of public discourse and as such tend to focus on metaphors that are commonly held across different societal groups often including but not limited to entrepreneurs (Anderson et al, 2009; Koiranen 1995). What such research does not tell us, is whether metaphors of entrepreneurship as some form of heroic activity, competitive sport, warfare and pilgrimage are used by entrepreneurs themselves to create meaning out of their experiences (Pitt, 1998)? 
Metaphors are by their very nature, inherently incomplete expressions of experience, so while current metaphors of entrepreneurship illuminate the heroism in venture creation, they are concealing and silencing other possible perspectives (Ortony, 1979). Critically examining and reflecting on the metaphors-in-use of entrepreneurs is important given this powerful and often unacknowledged force metaphor has on the creation of understanding and meaning. Although entrepreneurs' identity creation is inevitably influenced by the surrounding discourse on what it means to be an entrepreneur, such discourses are not 'monolithic' and may not constrain entirely the experience of entrepreneurs themselves (Cohen and Musson, 2002; Down and Reveley, 2004). Identities are rarely singular or fully integrated, but instead are complex, tensional and divided 'bursting with complexities and deeply felt nuanced and often contradictory elements' (Ford, 2006, p. 96; Brown, 2015). As Mathias and Williams (2017, p. 912) illustrate entrepreneurs do not necessarily have a singular identity; instead, they have a multiplicity of intra-individual identities each which 'incites unique motivations and goals that may be varied and not necessarily congruent'. Entrepreneurs exist in complex and ambiguous environments where identities are continuously contested and in flux (Cohen and Musson, 2000; Essers and Benshop, 2007; Ibarra, 1999). Such equivocal contexts where meanings are still emergent can make it difficult for entrepreneurs to linguistically articulate what exists at the level of cognition (Bird, 1989; Hill and Levenhagen, 1995). The assumption of a conceptual rather than linguistic basis of metaphor means metaphors may be accessed through other non-verbal modes of communication, to some extent circumventing the need for entrepreneurs to verbally articulate meaning. We argue below that through the creation of non-verbal metaphors through the modality of drawing, we can learn in less constrained ways about entrepreneurs' thoughts and understandings of their identities.

\subsection{Visual Metaphors and Drawing Theory}


While the vast majority of research on metaphor has focused on verbal metaphor, there is a small but growing body of literature showing how metaphor manifests itself not just in language but a multitude of modalities (Forceville and Urios-Aparisi, 2009). Multimodal metaphor has been examined in contexts such as advertising (Jeong, 2008; Phillips 2003), political cartoons (El Refaie, 2003), film (Whittock 1990) oral speech accompanied by gestures (Cienki and Müller 2008) and art and design (Cupchik, 2003; Feinstein, 1982). In the context of entrepreneurship, this type of work remains rare, however, there are a few notable exceptions. Cornelissen et al, (2012) explored metaphors in the speech and gesture of entrepreneurs communicating to employees and (prospective) investors about newly-launched ventures. They found little evidence of common cultural metaphors (adventure, heroism, warfare) of entrepreneurship and instead noticed how entrepreneurs systematically used metaphors in both speech and gestures that related to their basic embodied experience (e.g. forward movements, spatial manipulation of objects). The gestures worked to complement and amplify metaphors in language through presenting schematic, imagistic representations of scenarios that allowed them to be comprehended in an active and holistic manner rather than a mostly linear manner presented by speech (Cienki and Müller 2008). In another study, Smith (2015) examined visual metaphors evident in images on the front covers of entrepreneurship textbooks showing that metaphors of individualism and heroism, so common in linguistic metaphors of entrepreneurs, were largely absent.

These studies echo research in other disciplines on non-verbal metaphors that suggest metaphors created beyond the modality of language may offer additional and perhaps contrasting meanings to language-based understandings. This appears particularly the case in relation to visual metaphors i.e. metaphors created in pictorial form (ElRefaie, 2003). As Kress (2004, p.117) highlights, images represent 'the (transformed) recollection of the visually encountered world through the spatially organized mode,' in contrast text is 'the 
(transformed) recollection of the actionally experienced world through the temporally organized mode'. That is, written text is governed by the logic of time or temporal sequence, whereas visual images are governed by spatiality, composition, and simultaneity. Given images are unbounded from the linear logic necessary to language, the pictorial mimesis of representation can afford a more holistic representation of experience (Kress and van Leeuwen, 2001; Mitchell, 1994; Strati, 1999). While linguistic metaphors, so much a part of our everyday language, are typically used without much cognizance of the fact, the creation of visual metaphors (e.g. through art, film-making, photography, drawing etc.) involves reflection, critical thinking and decision-making in relation to the composition of the image. This reflective process gives shape to understanding and distils the meaning of experience for both the creator as well as their audiences (Feinstein 1982; Lorenz, 2010).

More than any other means through which visual metaphors are produced, drawing is 'a critical and reflective form of investigating ourselves and the way we encounter the world around us' (Garner, 2008, p.17; Rawson, 1969). Drawing, 'the fundamental pictorial act' (Rosand, 2002, p. 1), pre-dates written language and is one of the most primordial and universal means of human expression (Stiles, 2014). It is an embodied act involving the hand and its coordinated relationship with gaze and consists of traces and lines inscribed for expressive, informational and communicational purposes (Dantzic, 1999). Drawing differs from other graphic modes such as writing and numeration in having no strictly regularized notation, and ranges from imagined pictures, sketches and doodles to scientific diagrams, geographical maps and architectural designs (Arnheim, 1969). It represents the ways in which 'things' are interpreted by the drawer, rather than being a necessarily representative picturing of people, objects, places and events (Wolf and Perry, 1988). The 'pencil in hand' is used to record, question and direct thought processes, as drawing out ideas encourages us to explore meaning and make sense as we continue drawing (Kantrowitz. 2012). So it can be seen as an 
assistant to thinking and problem solving and plays a formative role in the work of artists, designers, engineers and architects as 'a touchstone and tool of creative exploration that informs visual discovery and enables the envisagement and development of perception and ideas' (Taylor, 2008, p.9; Duff and Davies, 2005; Strati, 2000).

We propose that investigating entrepreneurial experiences through the medium of drawing we can learn more about their thoughts and understandings of their identities. The word 'drawing' itself means 'to pull out', and in this sense evokes the 'revealing and concretizing internal mental images' of entrepreneurs as the hand works as a bridge between the imagining mind and the image emerging on the paper (Pallasmaa; 2009, p. 92). As Kantrowitz (2012, p. 3) notes ' $[\mathrm{t}]$ he act of drawing can be understood as the creation of a physical space to play with our thoughts outside the confines of our minds, to see and manipulate our ideas and perceptions in visible form'. Drawings offer a powerful means to understand entrepreneurial identities because of their 'meta-indexical quality' that is their ability to be a negotiation or boundary space 'for both explicit and yet-to-be-made-explicit knowledge' (Henderson, 1999, p.99; Vince and Broussine, 1996). As such, drawings loosen any singular logic of sense, allowing creative thought to work through imprecise structures and interim decisions (Ehrenzweig, 1967). The upshot is a meaningful form without its being final, and which admits to vagueness, incompleteness, spontaneity and chaos as well as order; in this way they are much like the ventures themselves. Like drawings, entrepreneurship is 'transitory, ephemeral and fleeting...complex and often intangible' both are malleable and flexible, being drawn and redrawn (Dodd and Anderson, 2007, p. 348). Striking a felicitous balance between precision and vagueness, drawings offer entrepreneurs the potential to symbolise the complexities of entrepreneurial life, allowing us researchers to develop insights into the multifaceted nature of the entrepreneurial experience.

\section{Methodology}




\subsection{Collecting Data}

Data were collected from twenty entrepreneurs during a training initiative based at a leading

UK Business School. The entrepreneurs were deemed to be involved in potentially high growth businesses and the aim of the programme was to allow them to interact with academics and leading business experts to facilitate and catalyse such growth. Our study was not part of the programme we were simply given access to the cohort. A short presentation was given to the entrepreneurs by one of the authors where the task was explained to them. They were asked to 'imagine an image or symbol that encapsulates or expresses what your business means to you and draw it on the paper provided'. They were given some A3 paper and graphite pencils of varied hardness along with charcoal that we felt afforded them some choice and fluidity, and indicated it was a task requiring time and effort. It was stressed we were not aiming at aesthetically skilled end-products to be judged on technique, and we assured them they would get an opportunity to discuss their drawing during a later interview. The entrepreneurs were invited to move around or outside the room to find a space where they felt comfortable. They were not forewarned prior to the session that they would be creating an image of their venture but they were given sufficient time (60 mins) to create the drawing, offering space for the authoring of self-image and encouraging active conceptualization (Literat, 2013; Gauntlett, 2007). Initially there was reticence, with some commenting they hadn't drawn since they were children, a common response by adults when asked to draw in research settings (Guillemin, 2004). In other drawing studies notably with children, but also in organizational settings, resistance has been expressed by leaving sheets intentionally blank (Vince and Warren, 2012), discarding drawings, or scrawling names or slogans (Scherer, 2016). We didn't encounter active resistance of this kind and after a few minutes and further clarifications all the entrepreneurs began to draw as they saw others in the group doing so. 
All the entrepreneurs produced a final image and it was explained that they would receive a follow up email to take part in an interview. In previous drawing studies in the organizational domain, participants are often encouraged to develop a collective construal of the drawings with a group of peers (Ward and Shortt, 2013; Warren and Vince, 2012). Participants verbalise their images almost immediately after completing the drawings through these group discussion or other means such as recording a series of words that evoke their immediate reactions to drawings (Vince and Broussine, 1996). The aim of these studies is the co-construction of the meaning of the images between participants while the original meaning of the drawing for the individual is not necessarily prioritised. Given our focus on identity we felt it important the entrepreneurs were not influenced by others but had the opportunity to discuss their drawings in private. In addition, we did not immediately ask participants to provide verbal representations of the images. Research has shown that encouraging participants to think through the words needed to verbalise a visual event too soon can distort and disrupt initial and future insights of these experiences (Kantrowitz, 2012; Schooler and Engstler-Schooler, 1990). This cognitive phenomenon known as 'verbal overshadowing' occurs when perceptual insights exceed verbal expertise, and conceptual and analogical reasoning is interrupted by trying to immediately frame meaning in linguistic terms (Chin and Schoolor, 2008; Westerman and Larson, 1997). Since our aim was to access alternative insights to what language alone can provide, we had a period of two-four weeks between the creation and discussion of the drawing, a gap which has been shown to minimise the potential for 'verbal overshadowing' (Melcher and Schooler, 2004).

The interview method invited the entrepreneurs to reflect deeply on their drawing and its relation to their experience of creating ventures, so illuminating how they (re)constructed an entrepreneurial identity. A third qualitative researcher who was otherwise not involved in the project conducted the interviews with the entrepreneurs. The researcher had expertise with 
qualitative interviewing and had been trained by one of the authors in conducting 'drawing' interviews (Guillemin, 2004; Rose, 2001). It was important that the authors themselves did not conduct the interviews as this allowed them to approach the analysis of the images and text separately (see below). During the interviews, the participants reflected on the drawings, working through possible meanings with the researcher, not only concerning the nature of the image but also the relationship between the image and their entrepreneurial identity. The drawings acted as 'talking sketches' for understanding, analysing, refining and negotiating entrepreneurs' understanding of their experience (Henderson, 2007). This 'process of dialogue and discussion...stimulated and guided by the procedure is as important as the art itself (Broussine, 2008, p. 84). The interviewer asked why a particular image was chosen, the reasoning behind the spatial organization of the components of the image, and whether any shading and emphasis in the image were in some way significant (Rose, 2001). As Guillemin (2004 p. 285) notes, it is not just the image that is important 'but also its arrangement on the page, its relationship to other images produced, its size, and the force or faintness with which the image is drawn'. From these aesthetic discussions, wider considerations about their orientation toward their venture, and how they made sense of their lives as entrepreneurs emerged, through the creation, reading and discussion of the image, almost as a form of iterative and recursive storytelling. Through this hermeneutic process (Phillips and Brown, 1993) the aim was to gain a rich and emerging awareness of how entrepreneurs made sense of their being in business. The interviews lasted from thirty to sixty minutes and were recorded and transcribed ready for analysis alongside the images.

\subsection{Data Analysis}

Previous research using drawing methodology has highlighted that images and the accompanying interview data should be seen as inextricably linked, requiring simultaneous not separate interpretation (Kearney and Hyle, 2004). We agree that the interpretation of the 
images should not stand independent from the participants' meaning creation, however, we present here a more fine-grained three-stage process which allows us to examine the images and text independently and then bring them together to collectively interpret. One author conducted the visual analysis while the other author conducted the textual analysis and then we jointly integrated both sets of data. This process ensured that meanings were not fixed too early in the process and that both visual and verbal modes were given equal weight.

The first part of the analysis examined how images are constructed to express metaphors visually, drawing on the social semiotics and visual grammar literature (Kress and van Leeuwen, 2006; O'Toole, 2010). This approach has been used in the analysis of visual metaphors (El Refaie, 2003; Feng and O’Hallaran, 2012; Koller, 2005), and more specifically in analysing artists' drawings (Riley, 2004) and children's drawings (Lodge, 2007). The author who had collected the visual data and had the most experience in working with visual data conducted the analysis of the images. This involved examining three interrelated components of visual 'grammar' or meaning making: representational meaning (representing the experiential world); interactive meaning (interacting with viewers); and compositional meaning (constructing the image) (Kress and van Leeuwen, 2006; Riley, 2004). The representational meaning is the literal representation in the drawing of an actor, action, objects or location i.e. what is depicted. After the literal reading comes an interactive one, moving from the denotative to the connotative level of meaning (Feinstein, 1982). The interactive function is reflected in how the images attract the viewer's interest and the way the viewer is being asked to consider the participants or objects in the image (O'Toole, 2010; Hofinger and Ventola, 2004). This includes where the viewers gaze is directed, where the focal point for the viewer is positioned (top, bottom, middle etc.) how far or close things are positioned to the viewer. Compositional meaning relates to the techniques and tools used to make visible the representational and interactive meaning including focus or sharpness, contrast and shading, 
heavy or jagged lines etc. So for example Image 3 depicts an individual/people in a fishing boat on the surface of a sea full of creatures (representational meaning), the images that most capture the viewers' attention are the larger, more detailed sea creatures at the bottom of the page which dominate the image (interactional meaning), the effect is created through the use of charcoal, shading and contrast (compositional meaning).

This semiotic analysis of the drawings examined the choices the entrepreneurs made about what to visually represent as salient in the drawings and how this was achieved. The second part of the analysis required an in-depth examination of the textual material from the interviews in order to develop insight into the linguistic meanings the entrepreneurs attached to the images. This part of the analysis was carried out independently by a second author with expertise in qualitative analysis who began by repeatedly and intensively reading the interview transcripts to become intimately familiar with the textual descriptions of the images. A grounded or inductive approach as suggested by Glaser and Strauss (1967), Miles and Huberman (1994) and Strauss and Corbin (1990) was followed to code the metaphors that the entrepreneurs evoked in their discussion of the images. Each transcript was coded individually as a means to inductively code the metaphors relating to each individual image. Early codes acted as signposting until the researcher noted the salient trends or patterns emerging in the data (Gioia et al, 2013). Codes were gradually reduced through a process of re-reading the coded data, determining the linkages between codes and checking for any redundancy in the coding. The stages overlapped and were highly recursive, moving through a series of analytic episodes and condensing the data into a more coherent understanding of the metaphors present in each transcript (Miles and Huberman, 1994). The author did not attempt to seek metaphors that existed across the transcripts as the next part of the analysis was to integrate the results from both the first analysis (the visual grammar of the images) and 
second parts of the analysis (inductive analysis of the text) to develop an insight into the metaphors present in each independent image.

In third stage of the process, the coder for the visual images did a close reading of the inductive textual data and the text coder did the same for the visual coding of the images. Then to develop a collective understanding and interpretation of the metaphors in the images, the two datasets were brought together and compared. The authors discussed each individual image and related interview as a separate case, and discussed their findings and observations within each case. Both authors returned back to the images and the transcripts together to respond to any points of difference in analysis, any misunderstandings or unanswered questions. By cycling through this procedure several times, we completed the identification of the metaphors evident in each of the images and accompanying transcripts to the satisfaction of both authors. In the description of the findings below the elements from the visual and textual analysis are evident, for example compositional elements are discussed alongside interpretations by the entrepreneurs. Our analysis showed within one image (and accompanying description) there were often multiple, nuanced and sometimes contradictory metaphors. This is not surprising since our aim was through the modality of drawing to enable the entrepreneurs to circumvent the inherent linear mode of speech - one thing leading to another - and present instead a complex set of interconnected elements 'all in one go' (Arnheim, 1969). While this is a particular strength of the drawing method, allowing the entrepreneurs to express co-occurring thoughts and meanings they may have found difficult to linguistically articulate outright, it also makes it difficult to categorise the images in a conventional sense. Each of the images are in a sense unique and aren't necessarily amenable to categorisation in the same way a qualitative text would be treated where we would allocate the early codes to sit within neatly formulated higher-level categories or themes. 
For presentational purposes of the findings below the images are loosely placed into three quite open categories. These categories, on the surface at least, resonate with some common linguistic metaphors found in entrepreneurship: metaphors of movement; metaphors of familial relationships; metaphors of organic growth. The intention behind placing the images in categories which relate to linguistic metaphors of entrepreneurship was not to reduce these complex, dynamic images to the common language-based metaphors of entrepreneurship. But rather to use these loose categories as a means of comparing and contrasting these images with what we know of entrepreneurial metaphors in the linguistic domain. The images did not always neatly fit even in this open porous categories, for example we found 'Image 5' to equally convey both a nurturing parent metaphor and the metaphor of organic growth. In these cases we categorized the drawing with what we felt resonated most strongly in the accompanying interviews. Another example is 'Image 2' which is clearly two images/metaphors, a separation also made apparent in the accompanying interview, so they were treated separately in the findings. Given space constraints not all the images are reproduced here, however, Appendix A describes the other images produced, an overview of the visual dimensions, sample quotes and core metaphors.

\section{Findings}

\subsection{Metaphors of movement}

Many of the images could be seen as representing some form of movement, progress or transport including ladders up mountains, rollercoasters, paths through fields etc. However, the images described a range of very different forms of movements in a range of directions (upwards, across, downwards). Image 1 below perhaps resonates most clearly with the conventional linguistic metaphor of 'life as a journey' where the less concrete experience of life is understood through the more concrete embodied experience of a journey (Lakoff and 
Johnson, 1980). Here the entrepreneur illustrates himself as a traveller journeying through

green fields with many alternative pathways, all leading to the same unspecifiable destination:

\section{INSERT IMAGE 1 ABOUT HERE}

It's all about a journey...I am here, I don't quite know where the end is because it drops over the horizon, it's a nice bright blue sunny day, all the fields are green, it's a pleasant journey, there is lots of decisions to be made, I don't quite know where I am going to end up but I will end up somewhere... There are signposts, I don't know if there's any particular thing on them but they are there to represent decision-making. So it's like you are here, what do you know? Which way do you go? And I am trying to portray that I don't think there's a wrong direction, very few decisions are bad - having spent time in the army I tell you if somebody dies that is a bad day. Short of that, nothing is that bad and nothing is irreparable, so whether it goes really well, you've got money in the bank or no money in the bank it doesn't really matter as long as the journey's okay. (Finance entrepreneur (male) - Image 1)

The journey metaphor has previously been identified in the entrepreneurship literature, for example, Dodd (2002) found that entrepreneurs used the journey metaphor to give meaning to their life-business narratives. However the drawing gives a fuller sense of the type of journey the entrepreneur is undertaking. This is a journey of a lone but content traveller, with different routes toward an unknown destination, where choices about the venture are represented as physical crossroads (Lakoff and Turner, 1989), without bad options. Perspective is used to create an image where the viewer's gaze is drawn to the bottom central foreground where the entrepreneur stands at the beginning of his journey. The entrepreneur appears to embrace continuous and on-going change, and emphasises the process over 'destination' absorbing failure as well as success. Whilst Image 2 shares this sense of movement towards an unspecified destination, it presents a more socially embedded entrepreneur:

\section{INSERT IMAGE 2 ABOUT HERE}

So I was thinking how do I feel about the business? I feel like it's exciting, it's exhilarating, it's terrifying, it's really scary sometimes, there's lots of people relying on me but also supporting me... and I feel I'm sort of only halfway down the cliff....I don't really know where the landing point will be but I do know there's lots of people down there egging me on and providing support...I think when I get there that is not 
the end of the business but that's maybe when I feel a little bit more comfortable. I think it will be a soft landing and that these people will look after me when we get there. (PR entrepreneur (female) - Image 2 left side)

The image is perhaps less about journeying and more akin to falling, the entrepreneur is flying towards her co-workers in a hang glider and her colleagues are holding out a crash mat ready to soften any potential fall. While there are others to support her there is also a simultaneous sense she is alone and notably exposed in a fragile vehicle and ultimately responsible if it crashes to the ground. At the same time as the pilot she has some, albeit limited, control over a vehicle that can be taken to places more resource-intensive vehicles might never reach, using found forces like wind and thermals that are beyond overt control. This is visually illustrated through the central positioning of her figure which is larger and comparatively more detailed than the stick figures of her colleagues below. She also faces towards the viewer with a wide open mouth expressing her fear but also enjoyment. The sense of movement continues in Image 3 where the entrepreneur understands himself as a fisherman fishing for the truly unique:

\section{INSERT IMAGE 3 ABOUT HERE}

This is me and my team in the top in the boat and we are fishing... sometimes you don't know what you are fishing for and so it is just trial and error and keep going and keep going and eventually you will get there. It is all too easy just to go out and catch some fish...you know everybody copies, it's an easy thing to do, let's just go out and look at what them lot are doing and you just end up like that line of fish across the top, just another fish in the sea. As you go further down that ocean, when you get right down to the bottom, then you start coming up with things that are really interesting and really unique and really different. But there are a lot fewer of them and they are a lot harder to find because you don't know what they are. If you go out there and just fish quickly then you will catch stuff but it will just be more of the same but if you fish deeper and go that extra mile and try harder then you will really discover some really interesting fish that are actually quite outstanding and very, very unusual and that is why [in the image] as you go down the fish become less fish like and a bit more bizarre and weird. (Graphic design entrepreneur (male) - Image 3) 
The emphasis is on 'keep going and keep going' pushing further downwards into unknowns, the deep, beyond simply 'copying' which is represented by the ordinary and unremarkable 'fish' floating on the surface and towards the 'bizarre and weird' or true innovation. The size and strange shape of these unusual creatures at the bottom of the image means the viewer's eye is drawn downwards. Through the use of charcoal the entrepreneur has created marks of graduated tones from light to dark to create the appearance of deeper water where the larger and more elaborate fish forms are represented in darker pencil. Fishing is an activity that has an uncertain outcome, nets can snare, a fish can get away, it is easy to become frustrated and give up. However, failures can teach the fisherman as much as his successes as he develops an understanding of his technique and eventually catches one of these mysterious dark creatures in the deep water. In the previous images there is an on-going search for the unknown, in contrast in Image 4 the entrepreneur has a very clear sense of his ultimate destination:

\title{
INSERT IMAGE 4 ABOUT HERE
}

\begin{abstract}
We are on a ladder towards a higher aspirational goal and also a higher life quality vision...so the ladder going through the middle is the ladder to the future which finishes with our end destination, our end vision which for us is a ski chalet of some sort in the Alps, so the strategy of the business is...trying to provide a value of some sort that will enable us to open up another chapter. So along the way you have got some other innovative parts of it that represent the business...we have to deliver things on time so there is a bus there with on-time on it, we do an awful lot of work on the telephone so that is why the phone is on there, a cup represents awards so on the way we want to be seen to be achieving good things, the hands represent that with us you are in safe hands, confident hands... the clock is there just to demonstrate that time is ticking, you only get so many weeks in the world to live, so there is a watchful eye on the clock saying don't let any minute go passed without thinking that you are trying to get to the vision point. (Event management entrepreneur (male) - Image 4)
\end{abstract}

This image evokes the source domain knowledge about climbing a ladder which is an effortful, self-propelled, motion upward and also the metaphor of 'success is vertical' so being successful is a movement upwards (Lakoff and Johnson, 1980). Progress towards the highest point on the ladder (the destination) is measured in terms of a series of objects passed 
along the way e.g. the bus, the phone, the award cup. Maintaining impetus is reflected by emphasising the passing of time with an eye watching a ticking clock; indeed measured movement suffuses the image. The hands which dominate the image due to their position, size, and darker shading, highlight the metaphor of how being in control (of his own and his clients' success) is having it your hands (Kovecses and Szabco, 1996). There is a distinct difference between this image and the previous three images, showing the entrepreneurs pursuing two disparate approaches to venture creation: something akin to causation in Image 4 (a planned strategy approach with an established vision) and in the first three images something effectuation akin to affect (seeking the absorbing and creating a world unknown where the world is still in-the-making) (Sarasvathy, 2008).

\subsection{Metaphors of familial relationships}

Some of the images appeared to be grounded in some form of relationship often associated with the idea of family. The metaphor of parenthood specifically has been shown by others to be a prevalent metaphor for understanding entrepreneurship as it portrays a sense of caring for and protecting the nascent venture (Dodd, 2002). Cardon et al (2005, p. 38) suggest parenthood and entrepreneurship 'require a kind of nurturing that usually entails selfsacrifice and the willingness to put the baby/venture's needs ahead of one's own, despite uncertain payoffs, often far in the future'. To some extent Image 5 chimes with the metaphor of parenthood where this clean energy entrepreneur envisages himself as nurturing and caring for his 'healthy' 'happy' venture:

\section{INSERT IMAGE 5 ABOUT HERE}

Our business is about nourishing nature, I see it as my baby, it's got to be healthy, got to be cared for and my business generates electricity from the water and from the sun...nurturing a happy baby I think that works both ways the business is a happy baby that we are nurturing but also the golden light that emanates from a baby and therefore has an effect on other people... you know how people coo over a lovely baby 
because it's so full of joy, the idea is what we should be doing should be full of joy. (Green energy entrepreneur (male) - Image 5)

A new venture like a new baby is helpless and defenceless without the parent/entrepreneur and both require time, energy, effort and nurturance. The (disembodied) hands holding the baby is a common visual image of infanthood which often represents protection (Lupton, 2014). In the entrepreneur's account, unlike a typical parents' unconditional love, the nurturing given to this baby needs to 'work both ways'; it has to be reciprocated. The entrepreneur talks about the 'golden light that emanates' from the baby and this triggers an image of a religious saint or of some form of saintliness as the baby (the venture) is almost depicted as a saviour for our planet. There is a sense of dependence on the baby alongside a commitment to giving back to the wider environment. Others were more immediate and literal when comparing experiences of family and business:

\section{INSERT IMAGE 6 ABOUT HERE}

I think the point of the baby represents when we started, it's sort of like developing the baby and nurturing it...we just recently had a baby ourselves, our first baby, so it was quite a poignant time for us, that was probably another link with the business, the family, like the business is part of the family so the business, the baby, the family, all that kind of links as well...it's kind of like my baby, you know...it's a young business and you know it's got to grow, potential and a lot of stuff to learn. (Lettings Agency Entrepreneur (male) - Image 6)

This comparison of having his first child with the new venture speaks of the strong connection the entrepreneur has to his new baby but also to his venture, both warranting strong emotional reaction and identification (Cardon et al, 2005). There is also a sense of business and family merging, each helping provide for the other, as an organizational unit.

The image itself appears to the viewer as almost quite sinister and creates a sense of unease due to the curious juxtaposition of an adult head on an infant's body. Some forms of analysis for example those coming from psychoanalytic perspective may perhaps see amalgamation of 
adult and child as reflecting some unconscious emotional response to entrepreneurial experience (Diem-Wille, 2001). There was nothing in the entrepreneur's discussion of the image to suggest the image held a darker meaning for him and it is most probably the result of the entrepreneur's basic artistic ability. The association of family, business agent, venture and family was expressed by other entrepreneurs:

\title{
INSERT IMAGE 7 ABOUT HERE
}

\begin{abstract}
Happiness is my work. I love doing it. The $\mathrm{H}$ - I have spelt it out, the $\mathrm{H}$ is the main business, is our home and the business. The A is the heart because I love what I do...I love doing it...it spells 'happiness' and then also what is important is my family as well...And there is the sun there because the sun is always shining because I'm happy with everything...that is how I perceive my work. It is work and home and family and love. (Retail entrepreneur (female) - Image 7)
\end{abstract}

This retail entrepreneur had her business premises and home at the same location, which she drew in her image, overlaid with the word 'happiness' which is the largest and central component of the image. This female entrepreneur emphasises the embeddedness of her venture and the connections between business, home and family. We see here not just evidence of women's association with the home and domesticity but also a challenging of this image with a merging of the private world of the home with the public world of work, independence and control over her own space (McDowell, 1999). Home, business and family is also represented in the image below:

\section{INSERT IMAGE 8 ABOUT HERE}

It represents safety for the future, for my family, for everything....it has multiple meanings to me, obviously we're a secure courier service so there is safety in that dimension we have to make sure everything is safe from important documents to blood samples, somebody's life could depend on us...but also it represents everything I have is locked up in the business as well...I've put everything into it, my retirement, my security for my home... it encompasses everything that I am, including my personal life and my family life, it makes sure me and my family can have security in life. (Courier service entrepreneur (male) - Image 8) 
This entrepreneur chooses to represent his venture, using the word 'safe' ascribed across the image of a physical locked 'security safe', a repository for valuables. For this entrepreneur rather than seeing the venture as representing risk, he sees it as providing security and 'safety for the future' for himself and his family. The word 'safe' is an antonym of the word 'risk' which occupies a central role in many definitions of entrepreneurship (Brockhaus, 1980; Hytti, 2005). This image appears to directly contradict common assumptions about entrepreneurship which is often seen as synonymous with risk where through creating a new venture, an individual appears to gamble their finances, reputation and their family's wellbeing. However, there is also a tension evident between the oppositional forces of 'safe' and 'risk', as if the venture does not succeed this safety is gone which is in itself a risk. Another word-based image similarly spelled out a single emotion:

\section{INSERT IMAGE 9 ABOUT HERE}

[My drawing] was basically focused on love and actually that's the thing that drives the interactions from the business, the interactions with the customers, the interactions with the guys who work in the business with our partners, community, it all focuses around that as a kind of central theme and that is not love in the Hollywood kind of soppy way... because I believe there are different forms of love, its love in the sense that you want the best for somebody, that you care about them, that you would go out your way for them and all those kinds of things I think comes from a deep sense from wanting the best for the other person, whoever that person will be, that's the way I would describe it. (Online education support entrepreneur (male) - Image 9)

Through this image comes a sense of care and conditioning in which the agent stands in relational intimacy and responsibility to others, making sense of entrepreneurial behaviour that otherwise might appear illogical from a rational economic perspective (Ogbor, 2000).

Visually the central element in the image is a 'love-heart', conventionally a symbol for caring or love (Serafini, 2011). Rather than being an individualised activity driven by solely by 
profit, entrepreneurship is represented here embedded in the discourse of family and as an intensely cooperative endeavour.

\subsection{Metaphors of organic growth}

Many of the images represented the venture itself undergoing organic growth, a meaning often evoked by images of trees and flowers. This may not be surprising since the growth metaphor brought from the domain of biology and accompanied by an array of theoretical terminology (braches, root, incubation, life cycle, stages, etc.) is common both among practitioner and academic communities (Aldrich and Martinez, 2001; Clarke et al, 2014; Morgan, 2006). Particularly because these entrepreneurs were on a training course where successful applicants were deemed to have high growth potential, it is possible they were influenced by this terminology. However, the images were much richer than the common metaphor of entrepreneurial growth. Trees for example seemed to express a sense that the businesses were 'rooted' in the community. As Broussine, $(2008$, p. 89) notes 'this symbol conveys balance, rootedness, health and "one-ness" with the world'. This sense of 'rootedness' and 'health', as well as growth, is expanded by the following image and text:

\section{INSERT IMAGE 10 ABOUT HERE}

I do see ourselves as a living, breathing thing that's come from somewhere...we worked for the university and the students' union marketing department and we put some strong roots down there.... from there we've decided to grow into several markets but all based upon where we've come from, but the idea is we started branching out in to different sectors etc. and the kind of potential of where we're going seems a bit endless at the minute but it is a bit blurred in places as well. Not all the vision is kind of completely set out. There is a bit of unknown, but in a positive way I see that. But also, for me the tree seems to keep popping up as a symbol, at different stages in my life. (Creative communications entrepreneur (male) - Image 10)

The roots of this full and healthy tree delve deep into the earth expressing a sense of belonging and place. While the entrepreneurs may be influenced by associations with 
biological growth in the media, policy environment and academia, this image evokes something intimate, retaining an important symbolic value in different stages of the entrepreneur's life. The entrepreneur spoke of the leaves on the edges of the tree reflecting the ambiguity of the future, less certain than the central trunk and its older roots. Visually this is represented by smaller, less developed, leaves with blurriness of their edges and form, contrasting with strong dark lines of the original tree. Similarly, in the image below the smaller 'incubated' flowers are used to reflect the business in the early years, while the current state of the business is reflected by large, fully formed, healthy flowers.

\title{
INSERT IMAGE 11 ABOUT HERE
}

\begin{abstract}
On the bottom left hand side there's a sort of incubated little flower, just growing and when my business started it ran from my parent's house... so it was very small scale but had everything that we needed and everybody knew what they needed to do as long as they stuck with each other... and then on the right is what happened after that, which was the company expanded and grew and then we had to just deal with all of the challenges of a growing company basically. And so the flowers are growing and they are pretty healthy. I have drawn some big storm clouds because part of the growth was quite stormy...In the top right hand corner there are bigger flowers above the clouds and they are sort of partially hidden, so I think that's where we are now, we are still growing and we are still healthy and the flowers are going off the edge of the picture because the story has yet to be written about the future (Education technology entrepreneur (female) - Image 11).
\end{abstract}

Like the previous image, Image 11 conveys ambiguity, and is historical as well as futureoriented, the venture having survived turbulent times suggested by dark storms clouds, and flowers are drawn as if they continue beyond the page into the venture's unknown future. Broussine (2008, p. 88) similarly found participants 'invested a lot of black ink in the depiction of heavy clouds and this was invariably used as a metaphorical device to communicate anxiety, danger or looming threats'. These complexities of struggle and unknown futures were also illustrated by tangled or twisted roots, whilst withered flowers and trees represented aspects of the business that were changing or failing. A more explicit rendering of these 'tangled roots' and 'withered flowers' is in Image 2 (right hand side): 
These are all the very complicated roots ... we have been all around the houses to get to the point where we have got these lovely flowers. There is the odd one that is dying, just because our service is changing now and so our business is changing. We have got some big flowers [which represent] the things that we do that are well established and these are all of our helper bees and these aren't the just the team actually, these are all the other people that help us do our business...people that we can ring and say 'we are in this situation can you help us?', or 'have you ever experienced this?' 'What would you do?' and I think that's incredibly important but the business...I think [this drawing] needed to be something organic because we did grow organically and it's only become a bit prettier really in the last two or three years I would say, a bit more proper. (PR Entrepreneur (female) - Image 2)

Image 2 also brings in the metaphor of 'helper bees', reflecting others integral to the venture's growth, just as, in an ecological sense, bees play an integral role in pollination and hence reproduction across generations. These 'bees' represent the dependency of the entrepreneur on their wider network. The entrepreneur's network extends the reach and abilities of her as an individual and allows her to access resources and knowledge held by others and so improving her entrepreneurial effectiveness (Jack and Anderson, 2002). This connection between the venture 'growing' into something ('proper', 'prettier') and wider community effort also comes across in Image 12:

\section{INSERT IMAGE 12 ABOUT HERE}

There are people hanging off the tree, I see it as a growth business that relies on our people, the people make the business, so they are the business. Without the people there is no business but also the fact that the end product is that we support people through our business so we are a people business through and through. We haven't grown enough yet, we will grow, we have got plans to continue to expand the business it's quite a solid tree...we want the foundations of the business to be well embedded before we grow too much. (Social enterprise entrepreneur (female) - Image 12)

While these images appear on the surface at least to be related to the linguistic metaphors of growth, they once again provide more nuanced insight. Unlike many organisms, the firms did not develop along predefined evolutionary paths by which they unfold into growth, instead there is much here about the importance of the broader social and cultural dynamics that embed start-ups and help them to flourish (Hoang and Antoncic, 2003). The entrepreneurs do 
not see their evolutionary survival and growth as hinging on the preservation of their own fixed and narrowly defined interests but rather on the more fluid and open interests of the system to which they belong (Greve and Salaff, 2003; Clarke et al, 2014). Image 13 depicted a simple, pencil drawn circle as a representation of the venture seemingly opposed to common understanding of the stages of growth in new ventures:

\section{INSERT IMAGE 13 ABOUT HERE}

This represents continuity, what the business means to me, it is something that is continuously flowing... this is where will we be in six months' time and where will we be in 12 months' time... When I come out of this building and maybe when you leave today just stop for a minute before you leave the glass doors, there is constantly people walking past and it's almost like this conveyor belt so I come out of there and I just join the conveyor belt again all just continuously goes on. (Website design entrepreneur (male) - Image 13).

Linguistic metaphors of growth normally point to the various stages of development that a firm (like an organism) should go through. Firms are seen to progress along linear growth trajectories, divided into periods characterised by distinctively different stages of development defined in term of emergence, growth and maturity, followed in due course by decline and death (Tsoukas, 1991). The image here represents a continuous, ongoing renewal within the business, perhaps resonating better with the ancient metaphor of the 'circle of life' or the 'sacred circle' that is unending and unbroken rather than the common metaphors of growth we see being used in relation to entrepreneurship (Regnier, 1994).

\section{Discussion}

In this study we elicited metaphors through a drawing methodology that allowed entrepreneurs the opportunity to thoughtfully and reflectively create images of their entrepreneurial identities. These drawings provided 'a departure point for apprehending something of [the entrepreneurs'] worlds and world-making' (Mitchell, 2006, p. 63) and were subsequently followed up with textual interviews helping to align the internal and the external 
narrative that shaped the drawing (Banks, 2001). The visual and verbal 'have different potentials, so that they afford different kinds of possibilities of human expression and engagement with the world, and through this differential engagement with the world they facilitate differential possibilities' (Kress, 2000, p. 157). We argue that through combining linguistic and visual meanings, with their own inherent affordances or possibilities for meaning creation we have been able to develop insights into entrepreneurial identities than would otherwise not have been expressed (Lemke, 2004). Therefore, we believe that eliciting metaphors of entrepreneurship through the modality of drawing offers new ways of conceptualising the entrepreneurial experience.

The findings of this study show that rather than representing idealized myths of the heroic or visionary entrepreneur, the metaphors elicited reflect the mutuality of business ventures and are what might be described as post-heroic. The entrepreneurs' idiosyncratic understandings of their identities emerged from local, contextually rich experience (Downing, 2005; Lounsbury and Glynn, 2001) into which prevailing discourse was woven, but not in overtly determining ways. Our findings illustrate entrepreneurial identities as dependent on a network of others with whom they must cooperate, support and motivate in order to even understand, let alone make a success of, opportunities that are entirely relational in their existence. Our study is a rare piece of empirical work focusing on entrepreneurs' own metaphorical struggle to make sense of their entrepreneurial experience, and the only study, to our knowledge, which has employed both visual and verbal meaning-making as a means of accessing entrepreneurs' understandings of their identities. We argue that this opportunity to deliberately and intentionally visually create, and verbally reflect on metaphors of their experience has allowed entrepreneurs to move away from common and often thoughtlessly produced linguistic metaphors of entrepreneurship and instead create post-heroic, postacquisition metaphors of entrepreneurship where dependency, embeddedness, experiment and 
interrelationships are expressed. Rather than seeing themselves as heroic individualists the entrepreneurs viewed their role as highly social and their ventures depicted as intensely cooperative endeavours where social assets such as friendship, dependence, trust, obligation and gratitude, played an integral role in their success (Jack and Anderson, 2002).

Despite this sense of dependency on others the entrepreneurs rarely expressed their role in negative or ambivalent terms, for example, dependency could perhaps invite representations of vulnerability or weakness. In fact the metaphors of entrepreneurial identities presented here had an overwhelmingly positive valence. Entrepreneurship has been identified as a sometimes traumatic and stressful experience where entrepreneurs face the possibility that the financial and personal commitments made to the business could result in major losses and jeopardise his or her future alongside the futures of family and employees (Cope, 2005). It is therefore likely that entrepreneurs may face at least occasional threats to their identity-making and identity sustaining activities. Yet there is little evidence of a 'darker side' of entrepreneurship here (Ket de Vries, 1985). The drawings and the accompanying verbal discussions capture the identity work of entrepreneurs where they frame and refocus potentially negative or ambivalent aspects of entrepreneurship to secure positive selfmeanings (Kreiner et al, 2006). For example, one entrepreneur acknowledges his reliance on the venture for his own and his family's future but through metaphorically presenting the venture as 'a safe' (Image 8) he highlights the security the venture provides his family rather than the potential risk. Another entrepreneur depicts entrepreneurship as a journey with multiple crossroads where he suggests there is no such thing as a 'bad' decision' (Image 1). Clearly bad decisions are possible and outcomes may be catastrophic for both entrepreneur and those in relation to them. This creation of images of identity and the reflection on and discussion of these images gives us a unique insight into how entrepreneurs choose to recast 
identity threats in more positive terms, through metaphors that emphasise possibility, progress and purpose in their lives (Ashforth, 2009; Ashforth and Kreiner, 1999; Roberts et al, 2009).

While the heroic entrepreneur metaphor is perhaps conspicuous by its absence, there was some evidence of metaphoric images that map onto those that others have identified in the linguistic domain (Cardon et al, 2005; Clarke et al, 2014; Dodd, 2002). For example, Image 1 very clearly speaks to the metaphor of a journey (Dodd, 2002) and in Images 5 and 6 there is an explicit reference to parenting and the protection of something that is nascent and fragile (Cardon et al, 2005). Given that these metaphors occur in both linguistic and visual modalities it is likely that these are common metaphors that entrepreneurs use to understand their experience, not at the level of language but at the level of thought and meaning-creation (Lakoff and Johnson, 1980, 1999). Even though these images relate to linguistic metaphors of entrepreneurship accessing both the visual and verbal meaning-making gave a much more nuanced insight into how these common metaphors are used by entrepreneurs. For example, metaphors of journeys are visually represented by routes that go sideways, upwards, outwards and downwards across different landscapes and terrains and signify different purposes and end goals. Metaphors of biological growth are represented by blossoming flowers, securely rooted trees, withering leaves, while the idiosyncratic reasoning underlying them was often not related to the typical understanding of growth in the entrepreneurship domain (Anderson and Korsgaard, 2011). The verbal discussion was particularly useful to illustrate that the metaphors were not used unreflectively, for example in Image 6 the entrepreneur chose to draw an image representing parenthood not because it is a prevalent metaphor of entrepreneurship but because for him it was a poignant representation for him for both his venture and the recent birth of first child.

Finally the findings also lay bare a series of tensions or paradoxes in the entrepreneurs' identities, suggesting that the experience of entrepreneurs is not only complex 
but contradictory in nature (Anderson et al, 2009). Examples of this co-existence of opposites includes depictions of the entrepreneur as embedded and dependent whilst also solitary and alone (Image 2 right hand side), the venture as a child that needs nurturing who must also be a provider (Image 5), offering security and at the same time an obvious risk (Image 8).

Entrepreneurial identities are multifaceted, encompassing potentially opposing experiences or contrary assumptions. Through allowing a process of reflection and meaning-making in both the linguistic and visual domains, our approach has enabled us to surface rather than suppress tensions in the experience of entrepreneurship. As Croghan et al. (2008, p.355) argue 'combining verbal and visual forms of self-presentation allows [entrepreneurs] more scope for presenting complex, ambiguous and contradictory versions of the self.' While a typical response to tensions 'is to attempt to resolve them, to create the familiar out of the strange, to rationalize them' (Farson, 1996, p. 13), we argue these tensions appear to exemplify the entrepreneurial condition itself. Embracing these tensions can allow us as researchers to go beyond oversimplified and polarised understandings and recognise the complexity, diversity and ambiguity of entrepreneurial experience (Cameron and Quinn, 1988). Awareness of this interplay between concealing and revealing seems to frame the development of the ventures themselves: it is only by encountering the concealed that entrepreneurs might then set about revealing the world differently. Since metaphors are inherently partial and both illuminate and hide, no singular or dominant metaphor will ever give us a perfect all-purpose view of entrepreneurial experience. Through recognising this we can begin to mobilise the true potential of metaphor where we can work with many competing understandings creating a mosaic of insights that allow us to explore the intricacies of entrepreneurial identity.

\subsection{Practical Implications}

Developing insight into entrepreneurs' metaphors-in-use or the 'conceptual viewpoint' of entrepreneurs can allow us to better engage with them and ultimately develop more useful 
and inclusive theories that resonate with the experience of entrepreneurs. The entrepreneurs themselves can also directly benefit through consciously and reflectively creating metaphors of their daily lived experience allowing them to surface rather than suppress, the rich, nuanced and messy nature of entrepreneurial experience. Drawings allows the opportunity to construct a 'virtual world' where 'the pace of action can be varied at will. The designer can slow down and think about what he is doing' (Schön, 1983, p. 159). This 'slowing down' process facilitates the entrepreneur's deep engagement in a cognitive act where through analogical reasoning the entrepreneurs to make sense of their identity, resulting in their realities becoming enriched, better understood and thereby broadened (Feinstein, 1982). As Kantrowitz (2012, p. 5) notes 'the physical act of drawing makes us more aware of the intricacies of our own minds, the complex interdependencies and recursive loops of perception and cognition. We learn to see the world around us with fresh eyes'. The entrepreneurs in this sample, expressed how the drawings aided them in clarifying their thoughts to identify 'what are we doing and where are we going and what is this thing about'. Some referred to the drawing as a 'motif', 'a blueprint' or guide for future action, a means to filter out unnecessary 'noise', conveying what really matters, not only about being in business but about their sense of self and their unique life perspective.

The process of drawing not only involves reflection and meaning making on the part of the entrepreneur but also those around them. The entrepreneurs in this study felt that through the creation of these visual symbols or "motifs" they could more easily express their core ideas to others so they could also share the meaning, building mutual understanding. As one entrepreneur put it 'it works very well for me, resonates with me and it is simplistic and I think people possibly might understand easily what it means' others planned to display the images in public view in their offices suggesting they could act as a 'conversation piece' or a way to initiate discussion and 'tell my story to others'. Research has shown that material 
artefacts, including drawings, can help to establish common ground and find areas of compatibility in values and beliefs (Clark, 1998). The multiple metaphor mappings inherent in the drawings can allow entrepreneurs and those around them navigate the plurality of experience, acknowledge tensions, and give meaning to disruptive experience, providing a vehicle to negotiate co-ordinated action. As Hill and Levenhagen (1995, p. 1069) note the contradictions inherent in metaphor 'provide a clear sense of intended direction but allow sufficient flexibility for effective implementation.' They allow for creativity whilst providing a sufficient amount of structure that can allow an entrepreneurial organization to work 'at the edge of chaos' (Pascale, 1999).

In addition, the techniques described in this paper could be further extended and adapted to work creatively with entrepreneurs and their teams. For example rather than functioning as an individual task, the drawings could be co-created between the entrepreneurs and others in the venture as a means a means to create a publicly negotiated metaphorical landscape (Vince and Broussine, 1996). Both the entrepreneur and relevant stakeholders can then be encouraged to add metaphorical elements to the drawing, progressively building on the original drawing and through this co-constructing the venture's future (Barner, 2008). It is also possible that once entrepreneurs become aware of metaphoric imagery and identify the metaphors they are using, they may find it useful to challenge or change these metaphors. As Weick (1979) notes the use of inappropriate metaphors or over-pursuing certain metaphors can reduce insight and shut down alternative understandings. In therapeutic settings, for example, individuals may be encouraged to conduct thought experiments where they reconstruct their experience alternative metaphors, thereby shifting their perspective and broadening their point of view (Boone and Bowman, 1996). It is possible that such transformative techniques could be used in the future with entrepreneurs as a means to investigate whether their use of particular metaphors are limiting their perceptions and 
appraise how new interpretations might better serve them in pursuit of their entrepreneurial goals.

\subsection{Limitations and Future Research}

This paper has introduced drawing into the field of entrepreneurship which previously has not been embraced seriously as a methodology in this domain. Drawings have been criticized in this regard for being subjective, partial and too difficult to interpret conclusively for research purposes (Bell et al, 2014). These concerns are not unfounded as drawing seldom attracts consensus views, but then nor does entrepreneurship. Instead, drawing 'invites frustration or obsession in attempting to clarify something with is slippery and irresolute in its fluid status' (Petheridge, 2008, p.28). Drawings also have the potential to be 'overinterpreted' where meanings are ascribed that the participant does not necessarily recognise and the researcher becomes the 'visual translator' directing the audience to what is important in the image and what it means (Mitchell, 2006). There are also limitations inherent in translating something from one mode into the other and it is unlikely that we can ever fully do justice verbally to something it that is by nature non-verbal and visual without some loss of meaning (Feintstein, 1982; Kress, 2000). Here we attempt to overcome these issues to some degree by acknowledging the fluid and emergent nature of the meaning in the image and supplementing our semiotic analysis with the testimony of the participants. We provide clear methodological guidelines for those wishing to use this method in the future.

This research is limited to the extent that it is based on only one cohort of entrepreneurs in the UK, who were part of university-based training programme and identified as having strong growth potential. The thriving nature of these ventures is perhaps reflected in the images most of which as discussed above had a primarily positive valence. It would interesting to examine the metaphors created by entrepreneurs who are in less secure 
situations or those that may be experiencing venture failure. Would their more precarious situation be reflected in the kinds of images they choose to draw? Or would the strong threat that failure poses to their identity inspire them to draw positive images akin to those of the more successful entrepreneurs in this study? Future research could examine the images created by another group of organizational actors (for example managers) and how their metaphors-in-use differ to those used by entrepreneurs. It is worth considering how changing the production site of images might impact on the type of images produced (Rose, 2001). For example, allowing entrepreneurs to create the drawings independently outside of a formal context may perhaps encourage deeper levels of reflection. The focus on visual metaphor could be extended beyond drawing, entrepreneurs could be asked to create photographs which represent their identities (Ray and Smith, 2012) or use already existing images that 'speak' to their entrepreneurial experience. It would be interesting to compare whether the metaphors elicited through these related, but different methods, are similar to those in this drawing based study. 


\section{References}

Aldrich, H.E. and Martinez, M.A., 2001. Many are called, but few are chosen: An evolutionary perspective for the study of entrepreneurship. Entrepreneurship Theory and Practice, 25(4), 41-56.

Anderson, A. R. Dodd, S. D. and Jack, S., 2009. Aggressors; winners; victims and outsiders. European schools' social construction of the entrepreneur. International Small Business Journal, 27(1), 126-136.

Anderson, A. R. and Smith, R., 2007. The moral space in entrepreneurship: an exploration of ethical imperatives and the moral legitimacy of being enterprising. Entrepreneurship and Regional Development, 19(6), 479-497.

Arnheim, R., 1969. Visual Thinking. Berkeley, LA: University of California Press.

Ashforth, B. E., 2009. Commentary: Positive identities and the individual. In in L. Morgan Roberts and J. Dutton (Eds.) Exploring Positive Identities and Organizations. London: Routledge, pp. 171-187.

Ashforth, B. E. and Kreiner, G. E., 1999. 'How can you do it?' Dirty work and the challenge of constructing a positive identity. Academy of Management Review, 24(3), 413-434

Banks, M., 2001. Visual Methods in Social Research London: Sage.

Barner, R., 2008. The dark tower: Using visual metaphors to facilitate emotional expression during organizational change. Journal of Organizational Change Management, 21, $120-137$

Bell, E., Warren, S. and Schroeder, J. E., 2014. The Routledge Companion to Visual Organization. London: Routledge.

Bird, B. J., 1989. Entrepreneurial Behavior. Glenview, IL: Scott, Foresman and Company.

Boone, R. K. and Bowman, V. E. 1996. Therapeutic metaphors: Gateways to understanding. International Journal for the Advancement of Counselling, 19(3), 313-327.

Brockhaus, R. H., 1980. Risk-taking propensity of entrepreneurs. Academy of Management Journal, 23(3), 509-520.

Broussine, M., 2008. Creative Methods in Organizational Research. London: Sage.

Brown, A.D., 2015. Identities and Identity Work in Organizations, International Journal of Management Reviews, 17(1), 20-40.

Cameron, K. and Quinn, R., 1988. Organizational paradox and transformation. In R. Quinn and K. Cameron, (Eds.). Paradox and Transformation. Cambridge, MA: Ballinger Publishing Company, pp. 1-18.

Cardon, M. S., Zietsma, C., Saparito, P., Matherne, B. and Davis, C., 2005. A tale of passion: New insights into entrepreneurship from a parenthood metaphor. Journal of Business Venturing, 20(1), 23-45.

Chin, J. M. and Schooler, J. W., 2008. Why do words hurt? Content, process, and criterion shift accounts of verbal overshadowing. European Journal of Cognitive Psychology, 20(3), 396-413.

Cienki A. and Müller C. (Eds.), 2008. Metaphor and Gesture. Amsterdam: John Benjamins.

Clark, A. 1998. Being There: Putting Brain, Body and World Together Again. Cambridge, MA: MIT Press.

Clarke, J. Holt, R and Blundel R., 2014. Re-imagining the growth process: (co)-evolving metaphorical representations of entrepreneurial growth. Entrepreneurship and Regional Development: An International Journal, 26(3-4), 234-256.

Cohen, L. and Musson, G., 2000. Entrepreneurial identities: reflection from two case studies. Organization, 7(1), 31-48.

Cope, J., 2005. Toward a dynamic learning perspective of entrepreneurship. Entrepreneurship Theory and Practice, 29(4), 373-397. 
Cornelissen, J., 2005. Beyond compare: Metaphor in organization theory. Academy of Management Review, 30(4), 751-764.

Cornelissen, J., Clarke, J. and Cienki, A., 2012. Sensegiving in entrepreneurial contexts: The use of metaphors in speech and gesture to gain and sustain support for novel business ventures. International Small Business Journal, 30(3), 213-241.

Croghan, R., Griffin, C., Hunter, J. and Phoenix, A., 2008. Young people's constructions of self: Notes on the use and analysis of photo-elicitation methods. International Journal of Social Research Methodology, 11(4), 345-356.

Cupchik, G. D., 2003. The 'interanimation' of worlds: Creative metaphors in art and design. The Design Journal, 6(2), 14-28.

Dantzic, C. M., 1999. Drawing Dimensions: A Comprehensive Introduction. Upper Saddle River, NJ: Prentice-Hall.

Diem-Wille, G., 2001. A therapeutic perspective: The use of drawings in child psychoanalysis and social science. In T. van Leeuwen and C. Jewitt, The Handbook of Visual Analysis. London: Sage, pp. 119133.

Dodd S. D., 2002. Metaphors and meaning: A grounded cultural model of us entrepreneurship. Journal of Business Venturing, 17(5), 519-535.

Dodd, S. D. and Anderson, A., 2007. Mumpsimus and the mything of the individualistic entrepreneur. International Small Business Journal, 25(4), 341-360.

Dodd, S. D. and deKonig, A., 2015. Enacting, experimenting and exploring metaphor methodologies in entrepreneurial. In H. Neergaard and Leitch, C. M. (Eds.) Handbook of Qualitative Research Techniques and Analysis in Entrepreneurship. MA: Edward Elgar, pp.109-138.

Down, S. and Reveley, J., 2004. Generational encounters and the social formation of entrepreneurial identity: 'young guns' and 'old farts'. Organization, 11(2), 233-250.

Down, S. and Warren, L., 2008. Constructing narratives of enterprise: clichés and entrepreneurial self-identity. International Journal of Entrepreneurial Behaviour and Research, 14(1), 4-23.

Downing, S., 2005. The social construction of entrepreneurship: Narrative and dramatic processes in the coproduction of organizations and identities. Entrepreneurship Theory and Practice, 29(2), 185-204.

Duff, L and Davies, J., 2005. Drawing: The Process. Bristol: Intellect Books.

Ehrenzweig, A., 1967. The Hidden Order of Art, Berkeley: University of California Press.

El Refaie, E., 2003. Understanding visual metaphors: The example of newspaper cartoons. Visual Communication, 2(1), 75-95.

Essers, C. and Benshop, Y. 2007. Enterprising identities: Female entrepreneurs of Moroccan or Turkish origin in the Netherlands. Organization Studies, 28(1), 49-69.

Farson, R., 1996. Management of the Absurd: Paradoxes in Leadership. New York: Simon and Schuster.

Fauchart, E. and Gruber, M. 2011. Darwinians, communitarians and missionaries: The role of founder identity in entrepreneurship. Academy of Management Journal, 54, 935-957.

Feinstein, H., 1982. Meaning and visual metaphor. Studies in Art Education, 23(2), 45-55.

Feng, D. and O'Halloran, K. L., 2012. Representing emotive meaning in visual images: A social semiotic approach. Journal of Pragmatics, 44, 2067-2084.

Forceville, C. and Urios-Aparisi, E., 2009. Multimodal Metaphor: Applications of Cognitive Linguistics. New York: Mouton de Gruyter.

Ford, J. (2006). Discourses of leadership: Gender, identity and contradiction in a UK Public Sector Organization. Leadership, 2(1), 77-99.

Garner, S., 2008. Writing on Drawing: Essays on Drawing Practice and Research. Chicago: University of Chicago Press. 
Gauntlett, D., 2007. Creative Explorations: New Approaches to Identities and Audiences. London: Routledge.

Gioia, D. A., Corley, K. G. and Hamilton, A. L., 2013. Seeking qualitative rigor in inductive research. Organizational Research Methods, 16(1), 15-31.

Glaser, B. S. and Strauss, A., 1967. The Discovery of Grounded Theory. Chicago: Aldine.

Greve, E. and Salaff, J. W., 2003. Social networks and entrepreneurship. Entrepreneurship and Theory and Practice, 28(1), 1-22.

Gundry, L. K. and Welsch, H. P., 2001. The ambitious entrepreneurs: High growth strategies of women-owned enterprises. Journal of Business Venturing, 16(5), 453-470.

Guillemin, M., 2004. Understanding illness: Using drawings as a research method. Qualitative Health Research, 14(2), 272-287.

Henderson, K., 1998. On Line and On Paper: Visual Representations, Visual Culture, and Computer Graphics in Design Engineering. Cambridge, MA: MIT Press.

Hill, R. C. and Levenhagen, M., 1995. Metaphors and mental models: Sensemaking and sensegiving in innovative and entrepreneurial activities. Journal of Management, 21(6), 1057-1074.

Hjorth, D., Holt, R. and -Steyaert, C. (2015) Entrepreneurship and process studies.International Small Business Journal, - -33(6), 599-611.

Hoang, H. and Antonic, B., 2003. Network-based research in entrepreneurship: A critical review. Journal of Business Venturing, 18(2), 165-187.

Hoang, H. and Gimeno, G., 2010. Becoming a founder: How founder role identity affects entrepreneurial transitions and persistence in founding. Journal of Business Venturing, 25(1), 41-53.

Hofinger, A. and Ventola, E., 2004. Multimodality in operation: Language and picture in a museum. In E. Ventola, C. Charles and M. Kaltenbacher (Eds.) Perspectives on Multimodality. Amsterdam: John Benjamins Publishing, pp. 193-210.

Hytti, U. 2005. New meanings for entrepreneurs: From risk-taking heroes to safe-seeking professionals. Journal of Organizational Change Management 18(6), 594-611.

Ibarra, H. (1999). Provisional selves: Experimenting with image and identity in professional adaptation. Administrative Science Quarterly, 44(4), 764-791.

Jack, S. and Anderson, A., 2002. The effect of embeddedness on the entrepreneurial process. Journal of Business Venturing, 17(5), 467-487.

Jeong, S. H., 2008. Visual metaphor in advertising: Is the persuasive effect attributable to visual argumentation or metaphorical rhetoric? Journal of Marketing Communications, 14(1), 59-73.

Kantrowitz, A., 2012. The man behind the curtain: what cognitive science reveals about drawing. The Journal of Aesthetic Education, 46(1), 1-14.

Kearney, K. S. and Hyle, A. E., 2004. Drawing out emotions: the use of participant-produced drawings in qualitative inquiry. Qualitative Research, 4(3), 361-382.

Kemp, L. J., 2016. 'Trapped' by metaphors for organizations: Thinking and seeing women's equality and inequality. Human Relations, 69(4), 975-1000.

Ket de Vries, M. F. R., 1985. The dark side of entrepreneurship. Harvard Business Review, 85(6), 160-167.

Koiranen, M., 1995. North European Metaphors of 'Entrepreneurship' and 'an Entrepreneur' In Bygrave et al (Eds.) Frontiers of Entrepreneurship Research. Waltham MA: P \& R Publications, pp. 203-216.

Koller, V., 2005. Designing cognition: Visual metaphor as a design feature in business magazines. Information Design Journal and Document Design, 13(2), 136-150.

Korsgaard, S. and Anderson, A. R., 2011. Enacting entrepreneurship as social value creation. International Small Business Journal, 29(2), 135-151. 
Kovecses, Z. and Szabco, P., 1996. Idioms a view from cognitive semantics. Applied Linguistics, 17(3), 326-355.

Kreiner, G. E., Ashforth, B. E. and Sluss, D. M., 2006. Identity dynamics in occupational dirty work: Integrating social identity and system justification perspectives. Organization Science. 17(5), 619-636.

Kress, G., 2000. Design and Transformation: New Theories of Meaning. In B. Cope and M. Kalantzis (Eds.) Multiliteracies: Literacy Learning and the Design of Social Futures. London: Routledge, pp. 153-61.

Kress, G., 2004. Reading images: Multimodality, representation and new media. Information Design Journal, 12(2), 110-119.

Kress, G. and van Leeuwen, T., 2001. Multimodal Discourse: The Modes and Media of Contemporary Communication. London: Edward Arnold.

Kress, G. and van Leeuwen, T., 2006. Reading images: The Grammar of Visual Design. London: Routledge.

Lakoff, G., 1993. The contemporary theory of metaphor. In A. Ortony (Ed.), Metaphor and Thought. Cambridge: Cambridge University Press, pp. 202-251.

Lakoff, G. and Johnson, M., 1980. Metaphors We Live By. Chicago: University of Chicago Press.

Lakoff, G. and Johnson, M., 1999. Philosophy in the Flesh: The Embodied Mind and its Challenge to Western Thought. New York: Basic Books.

Lakoff, G. and Turner, M., 1989. More Than Cool Reason: A Field Guide to Poetic Metaphor. Chicago: Chicago University Press.

Lane, S. M. and Schooler, J.W., 2004. Skimming the surface: Verbal overshadowing of analogical retrieval. Psychological Science 15(11), 715-719.

Lemke, J. L., 2004. Multiplying intelligences: Hypermedia and social semiotics. In J. Kincheloe and A. Johnson (Eds.) Multiple Intelligences Reconsidered: An Expanded Vision. New York: Peter Lang, pp. 177-200.

Lewis, M., 2000. Exploring paradox: Toward a more comprehensive guide. Academy of Management Review, 25(4), 760-776.

Literat, I., 2013. 'A Pencil for Your Thoughts': Participatory Drawing as a Visual Research Method with Children and Youth. International Journal of Qualitative Methods, 12, 84-98.

Lodge, C., 2007. Regarding learning: Children's drawings of learning in the classroom. Learning Environments Research, 10(2), 145-156.

Lorenz, L. S., 2010. Visual metaphors of living with brain injury: Exploring and communicating lived experience with an invisible injury. Visual Studies, 25(3), 210223.

Lounsbury, M. and Glynn M. A., 2001. Cultural Entrepreneurship: Stories, legitimacy, and the acquisition of resources. Strategic Management Journal, 22(6-7), 545-564.

Lundmark, E. and Westelius, A., 2014. Entrepreneurship as elixir and mutagen. Entrepreneurship Theory and Practice, 38(3), 575-600.

Lupton, D. (2014). Precious, pure, uncivilised, vulnerable: Infant embodiment in Australian popular media. Children and Society, 28(5), 341-351.

Maclean, M., Harvey, C., Gordon, J. and Shaw, E., 2015. Identity, storytelling and the philanthropic journey. Human Relations, 68(10), 1623-1652.

Mathias, B.D. and Williams, D.W. 2017. The impact of role identities on entrepreneurs' evaluation and selection of opportunities. Journal of Management, 43 (3): 892-918.

McDowell, L., 1999. Home, Place and Identity, in L. McDowell (ed.) Gender, Identity and Place: Understanding Feminist Geographies. Cambridge: Polity Press, pp. 71-95. 
Meyer, A. D., 1991.Visual data in organizational research. Organization Science 2(2), 218236.

Miles, A. M. and Huberman, M. B., 1994. Qualitative Data Analysis: An Expanded Sourcebook. Thousand Oaks, California: Sage.

Mitchell, W. J. T., 1994. Picture Theory: Essays on Verbal and Visual Representation, Chicago: University of Chicago Press.

Mitchell, L., 2006. Child-centred? Thinking critically about children's drawings as a visual research method. Visual Anthropology Review, 22(1), 60-73.

Morgan, G., 2006. Images of Organization. Thousand Oaks, California: Sage.

Näslund, L. and Pemer, F. (2012). The appropriated language: Dominant stories as a source of organizational inertia. Human Relations, 65(1), 89-110.

Navis, C., and Glynn, M A (2010) How new market categories emerge: Temporal dynamics + of legitimacy, identity and entrepreneurship in satellite radio, 1990-2005. Administrative Science Quarterly, 55(3), 439-471.

Nicholson, L. and Anderson, A. R., 2005. News and nuances of the entrepreneurial myth and metaphor: Linguistic games in entrepreneurial sense-making and sense-giving. Entrepreneurship Theory and Practice, 29(2), 153-172.

Ogbor, J. O., 2000. Mythicizing and reification in entrepreneurial discourse: Ideology-critique of entrepreneurial studies. Journal of Management Studies, 37(5), 605-635.

Ortony, A., 1979 (Ed.). Metaphor and Thought. London: Cambridge University Press.

O'Toole, M., 2010. The Language of Displayed Art, 2nd ed. London: Routledge.

Pallasmaa, J., 2009. The Thinking Hand: Existential and Embodied Wisdom in Architecture. Chichester: Wiley.

Pascale, R. T. 1999. Surfing the edge of chaos. Surfing the edge of chaos. Sloan Management Review, Spring, 83-94.

Petheridge, D., 2008. Nailing the liminal: The difficulties of defining drawing. In S. Garner (Ed.) Writing on Drawing: Essays on Drawing Practice and Research. Chicago: University of Chicago Press, pp. 27-42.

Perren, L. and Adkin, R., 1997. Owner-manager's discourse: The metaphors-in-use. Journal of Applied Management Studies, 6(1), 47-61.

Pitt, M., 1998. A tale of two gladiators: 'Reading' entrepreneurs as texts. Organization Studies, 19(3), 387.

Phillips, B., 2003. Understanding Visual Metaphor in Advertising. In L. Scott and R. Batra (Eds.) Persuasive Imagery: A Consumer Response Perspective. Mahwah, NJ: Lawrence Erlbaum Associates, pp. 297-310.

Phillips, N. and Brown, J., 1993. Analyzing communications in and around organizations: A critical hermeneutic approach. Academy of Management Journal, 36(6), 1547-1576.

Powell, E. E. and Baker, T. 2014. It's what you make of it: Founder identity and enacting strategic responses to adversity. Academy of Management Journal, 57, 1406-1433.

Rawson, P., 1969. Drawing. Oxford: Oxford University Press.

Ray, J. L. and Smith, A. D., 2012. Using photographs to research organizations: Evidence, considerations, and application in a field study. Organizational Research Methods, 15(2), 288-315.

Regnier, R., 1994. The sacred circle: A process pedagogy of healing. Interchange, 25(2), 129144.

Riley, H., 2004. Perceptual modes, semiotic codes, social mores: A contribution towards a social semiotic of drawing. Visual Communication, 3(3), 294-315.

Roberts, M. L. and Dutton, J. E., 2009 (Eds.). Exploring Positive Identities and Organizations: Building a Theoretical and Research Foundation. London: Routledge.

Formatted: Font: (Default) Times New Roman, (Asian) Times New Roman, Complex Script Font: Times New Roman

Formatted: Normal, Indent: Before: $0 \mathrm{~cm}$, Hanging: 1.25 $\mathrm{cm}$

Formatted: Font: (Default) Times New Roman, (Asian) Times New Roman, Complex Script Font: Times New Roman 
Rosand, D.; 2002. Drawing Acts: Studies in Graphic Expression and Representation. Cambridge: Cambridge University Press.

Rose, G., 2001.Visual Methodologies. London: Sage

Sarasvathy, S., 2008. Effectuation: Elements of Entrepreneurial Experience. Cheltenham: Edward Elgar.

Schön, D. A. 1983. The Reflective Practitioner. New York: Basic Books.

Schooler, J. W. and Engstler-Schooler, T. Y., 1990. Verbal overshadowing of visual memories: Some things are better left unsaid. Cognitive Psychology 22, 36-71.

Smith, R. J., 1999. Social/personality Psychology in Context. Theory and Psychology, 9(6), 769-786.

Smith, R., 2015. Contextualising images of enterprise: An examination of visual metaphors used to represent entrepreneurship in text books. In H. Neergaard and C. M. Leitch, Handbook of Qualitative Research Techniques and Analysis in Entrepreneurship, Cheltenham: Edward Elgar, pp. 139-169.

Steen, G., 2014. The cognitive-linguistic revolution in metaphor studies. In J. Taylor and J. Littlemore, (Eds.) The Bloomsbury Companion to Cognitive Linguistics London: Continuum Publishing, pp. 117-138.

Stiles, D. R., 2011. Disorganization, disidentification and ideological fragmentation: Verbal and pictorial evidence from a British business school. Culture and Organization 17(1), 5-30.

Strati, A., 1999. Organization and Aesthetics. Sage: London.

Strati A., 2000. The Aesthetic Approach in Organization Studies. In H. Hopfl \& S. Linstead (Eds.) The Aesthetics of Organization Sage: London pp.13-34

Strauss, A. and Corbin, J., 1990. Basics of Qualitative Research: Techniques and Procedures for Developing Grounded Theory. Thousand Oaks, CA: Sage.

Taylor, A. 2008. Forward - re: positioning drawing. S. Garner (Ed.) Writing on Drawing: Essays on Drawing Practice and Research. Chicago: University of Chicago Press.

Tsoukas, H., 1991. The missing link: A transformational view of metaphors in organizational science. Academy of Management Review, 16(3), 566-585.

Vince, R. and Broussine, M., 1996. Paradox, defense and attachment: Accessing and working with emotions and relations underlying organizational change. Organization Studies, 17(1): 1-21.

Vince, R. and Warren, S., 2012. Participatory Visual Methods. In C. Cassell and G. Symon. Catherine (Eds.) The Practice of Qualitative Organizational Research: Core Methods and Current Challenges. London: Sage, pp. 275-296.

Ward, J. and Shortt, H., 2013. Evaluation in management education: A visual approach to drawing out emotion in student learning. Management Learning 44(5), 435-452.

Weick, K. 1979. The Social Psychology of Organizing ( $2^{\text {nd }}$ ed.). Reading, MA. AddisonWesley.

Westerman, D. L and Larson, J. D., 1997. Verbal-overshadowing effect: Evidence for a general shift in processing. The American Journal of Psychology, 110, 417-428.

Whittock, T., 1990. Metaphor and Film. Cambridge: Cambridge University Press.

Wolf, D. and Perry, M. D., 1988. From endpoints to repertoires: Some new conclusions about drawing development. Journal of Aesthetic Education, 22(2), 17-34.

Zuboff, S., 1988. In the Age of the Smart Machine: The Future of Work and Power. New York: Basic Books. 
Entrepreneurs Images of their Ventures

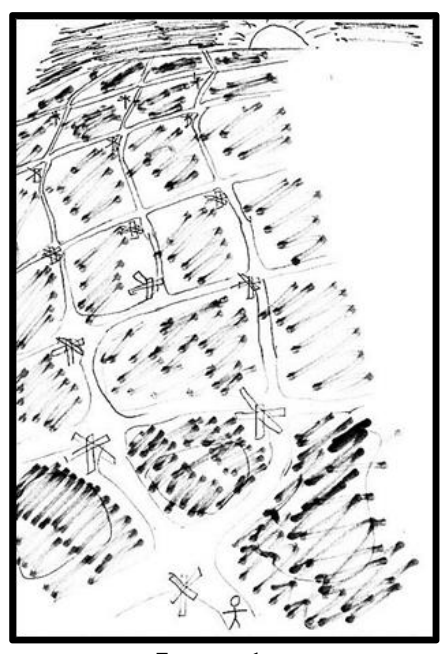

Image 1

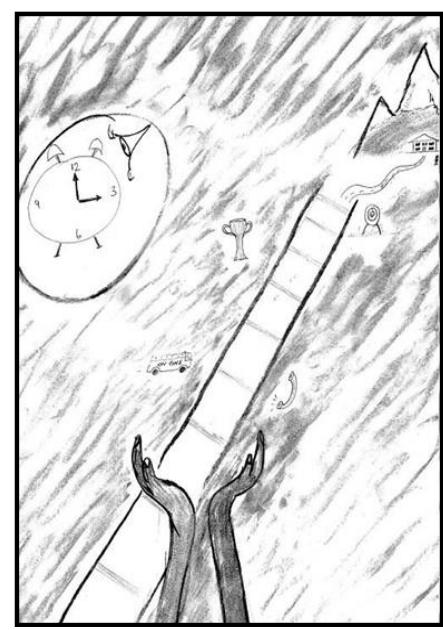

Image 4

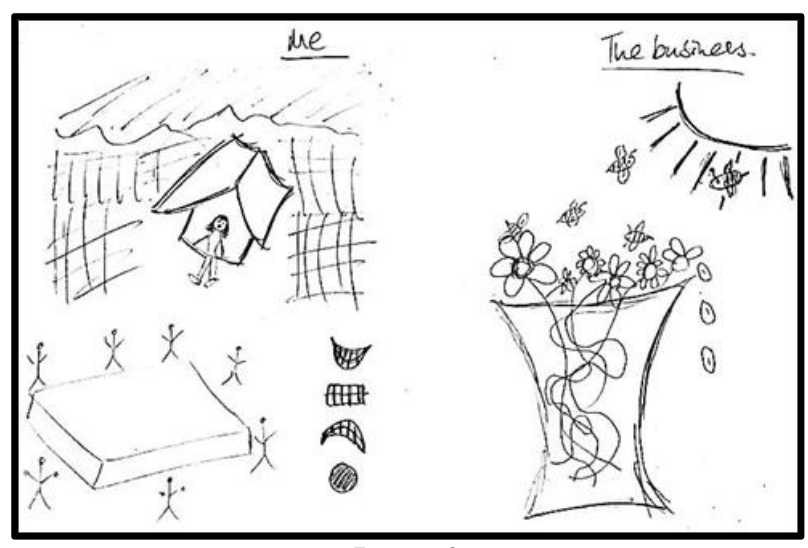

Image 2 


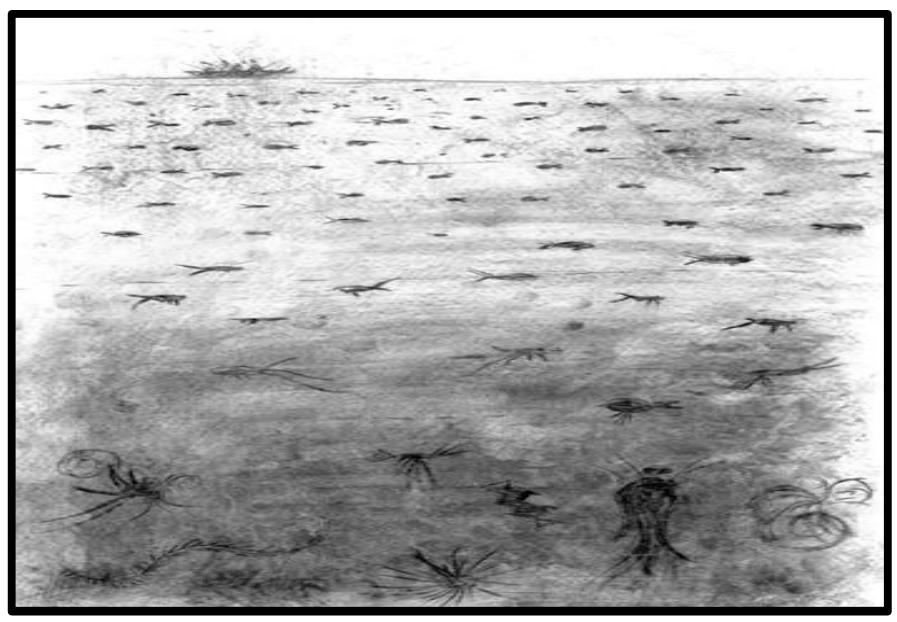

Image 3

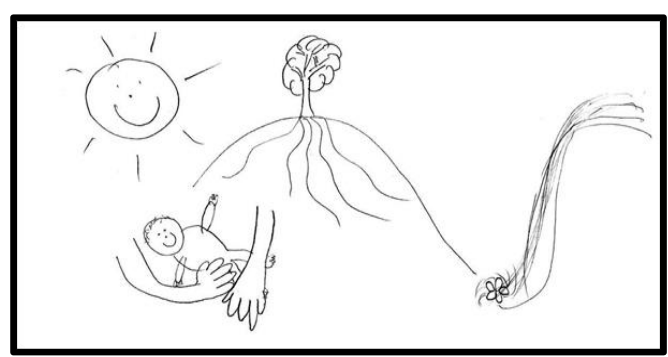

Image 5

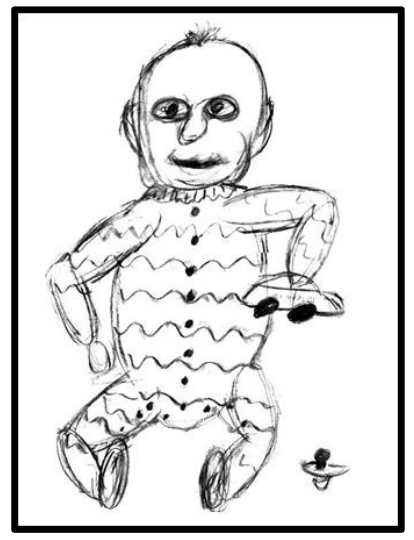

Image 6 


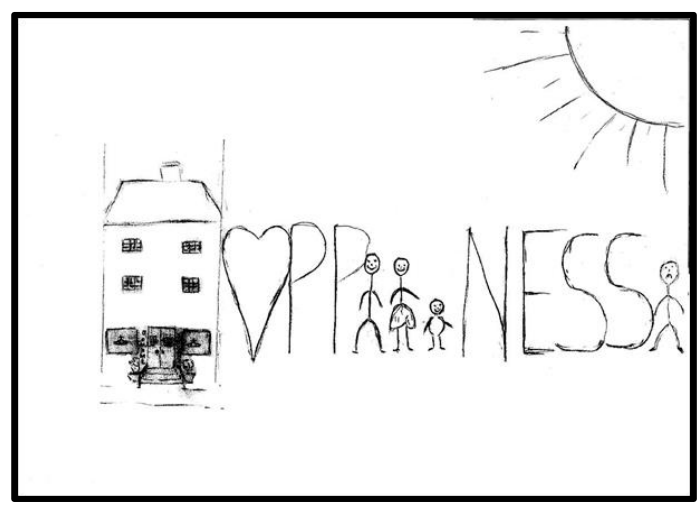

Image 7

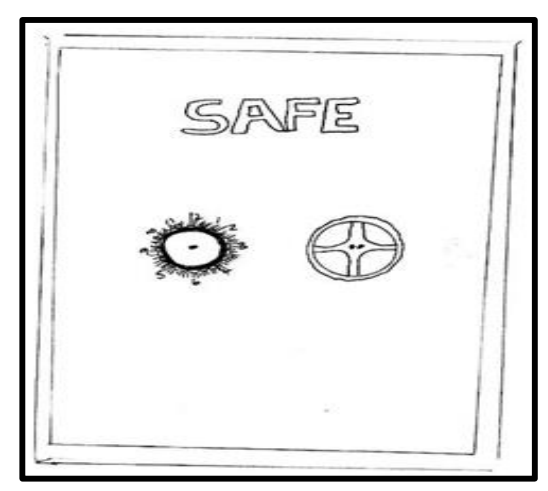

Image 8

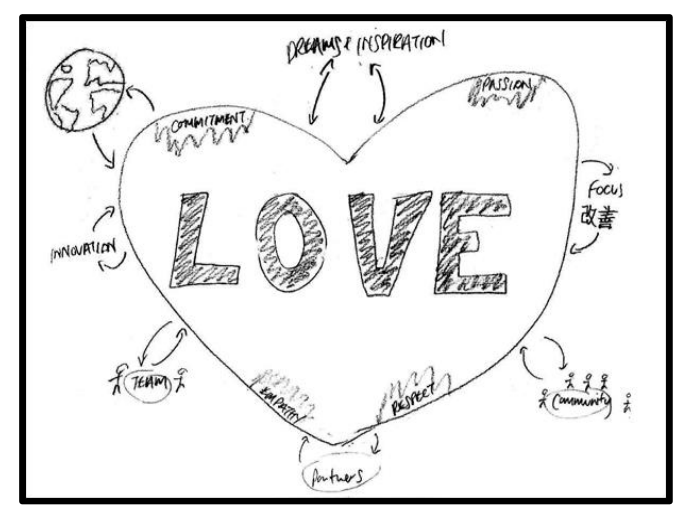

Image 9 


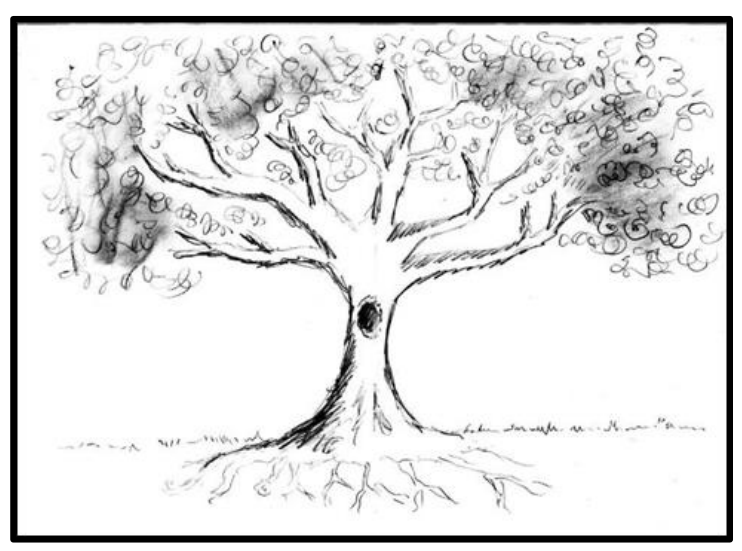

Image 10

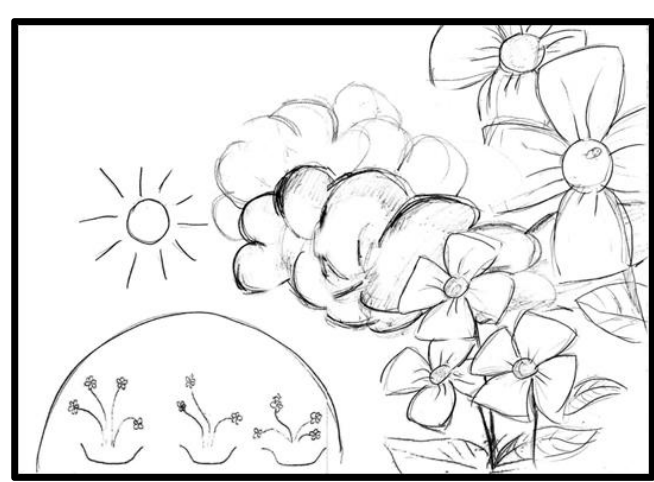

Image 11 


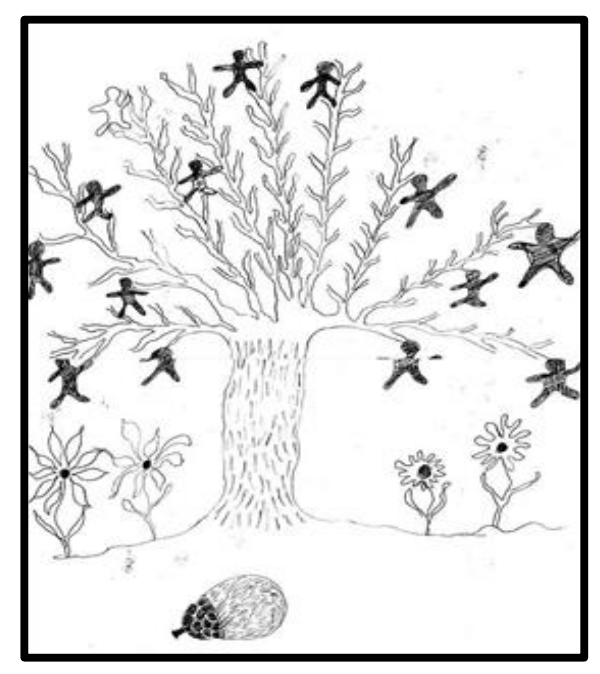

Image 12

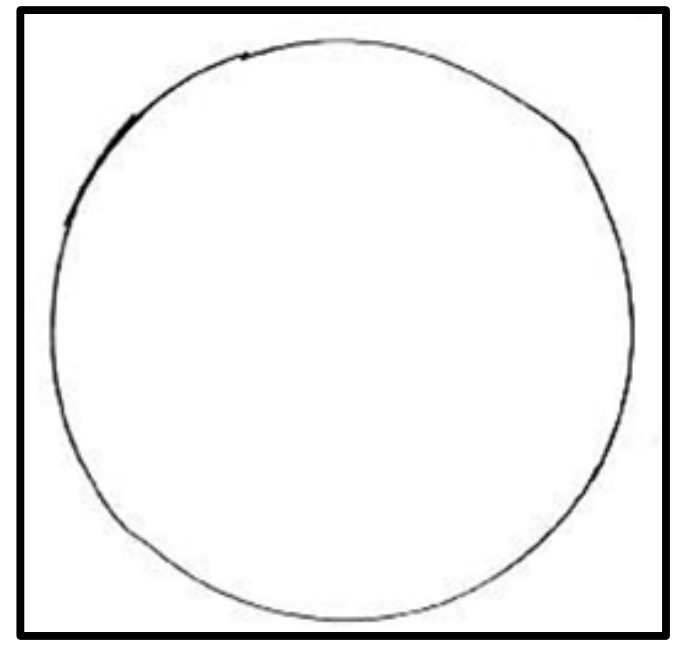

Image 13 


\section{Appendix A: Description of images not included in paper}

\begin{tabular}{|c|c|c|c|c|}
\hline $\begin{array}{l}\text { Representational: } \\
\text { Description of Image }\end{array}$ & $\begin{array}{l}\text { Interactive: How the image } \\
\text { attracts the viewer's interest }\end{array}$ & $\begin{array}{l}\text { Composition: How is it } \\
\text { depicted }\end{array}$ & Sample Quote: & Core Metaphors \\
\hline $\begin{array}{l}\text { 'Mandelbrot set' (a } \\
\text { mathematical equation } \\
\text { related to Chaos Theory) } \\
\text { IT entrepreneur - male }\end{array}$ & $\begin{array}{l}\text { Central to the drawing is the } \\
\text { image associated with the } \\
\text { 'Mandelbrot set' which takes up } \\
\text { almost all of the page. }\end{array}$ & $\begin{array}{l}\text { The image is depicted in } \\
\text { dark charcoal illustrating a } \\
\text { close zooming in to a } \\
\text { computer generated } \\
\text { Mandelbrot set. }\end{array}$ & $\begin{array}{l}\text { This is called the fractal picture...I'm very sure that } \\
\text { very simple mathematical equations can turn into } \\
\text { beautiful outcomes...you're just repeating the same } \\
\text { thing, feedback, constantly feedback, on how the } \\
\text { business is run. }\end{array}$ & $\begin{array}{l}\text { Flow/ Circular } \\
\text { movement/non- } \\
\text { linear } \\
\text { Mathematical } \\
\text { formula }\end{array}$ \\
\hline $\begin{array}{l}\text { A person on a rollercoaster } \\
\text { Recruitment } \\
\text { entrepreneur - male }\end{array}$ & $\begin{array}{l}\text { A sense of tension is created by } \\
\text { the entrepreneur being } \\
\text { positioned at the critical } \\
\text { precipice of a rollercoaster just } \\
\text { coming up to a steep dip. }\end{array}$ & $\begin{array}{l}\text { The roller coaster is } \\
\text { illustrated in light pencil } \\
\text { while the entrepreneur in the } \\
\text { rollercoaster car is drawn in } \\
\text { a much darker shade. }\end{array}$ & $\begin{array}{l}\text { Well I used to work in a fairground back in my } \\
\text { much younger days, so it's an image that comes to } \\
\text { me when I think about running a business is very } \\
\text { much like a rollercoaster....there have been many } \\
\text { ups and downs and twists and turns along the way. }\end{array}$ & $\begin{array}{l}\text { Movement up and } \\
\text { down/ Journey } \\
\text { Fairground }\end{array}$ \\
\hline $\begin{array}{l}\text { A person entering a forest } \\
\text { Social enterprise } \\
\text { entrepreneur }- \text { female }\end{array}$ & $\begin{array}{l}\text { The viewer's gaze is directed } \\
\text { towards the entrepreneur who is } \\
\text { central in the image, and } \\
\text { depicted as almost as large as } \\
\text { the trees. }\end{array}$ & $\begin{array}{l}\text { The entrepreneur is a hazy } \\
\text { figure drawn in heavy } \\
\text { charcoal. The trees further } \\
\text { away are blurred to give the } \\
\text { impression of distance. }\end{array}$ & $\begin{array}{l}\text { I enjoy going to the forest, I find it a peaceful place } \\
\text { where I can gain some insight and reflect, I also } \\
\text { enjoy meditation...I think that the forest also } \\
\text { represents the business...I'm not sure what or } \\
\text { where the outcome is but is certainly testing me, } \\
\text { challenging me, developing my inner strength. }\end{array}$ & $\begin{array}{l}\text { Movement/ } \\
\text { Journey/ } \\
\text { Adventure/ } \\
\text { Trail }\end{array}$ \\
\hline $\begin{array}{l}\text { An Apple computer } \\
\text { mouse, flowing into a } \\
\text { brain and a light bulb and } \\
\text { people underneath getting } \\
\text { electrified with ideas } \\
\text { through lightning bolts. } \\
\text { PR and communications } \\
\text { entrepreneur - female }\end{array}$ & $\begin{array}{l}\text { The viewer's gaze is drawn to } \\
\text { the Apple mouse which is much } \\
\text { larger than the other elements in } \\
\text { the image. It is for example } \\
\text { almost three times the size of } \\
\text { the brain. The people are the } \\
\text { smallest and least detailed part } \\
\text { of the image. }\end{array}$ & $\begin{array}{l}\text { The mouse is competently } \\
\text { drawn in fine pencil in a } \\
\text { realistic style. The lightning } \\
\text { bolts are shaded to give } \\
\text { them a three dimensional } \\
\text { shape. Lines are drawn } \\
\text { moving away from the } \\
\text { lightbulb to depict light. }\end{array}$ & $\begin{array}{l}\text { I started with the mouse because we work in design } \\
\text { and then that's leads to a little brain, because we do } \\
\text { a lot of thinking and creativity stuff in the business, } \\
\text { the brain leads to the ideas because we have to have } \\
\text { lots of ideas and keep coming up with new ideas } \\
\text { and so it's a bit like a flowchart I guess. It's a } \\
\text { continuous thing it could kind of start anywhere but } \\
\text { the ideas we create, have to be ideas that spark } \\
\text { people. }\end{array}$ & $\begin{array}{l}\text { Flow/ } \\
\text { Movement/ } \\
\text { Ideas as light }\end{array}$ \\
\hline
\end{tabular}




\begin{tabular}{|c|c|c|c|c|}
\hline $\begin{array}{l}\text { An image of lips, one ear } \\
\text { and an eye inside a heart } \\
\text { Video production } \\
\text { entrepreneur - female }\end{array}$ & $\begin{array}{l}\text { Visually the central element in } \\
\text { the image is the 'love-heart' all } \\
\text { other elements are positioned } \\
\text { within the heart symbol. }\end{array}$ & $\begin{array}{l}\text { The heart is drawn simply in } \\
\text { pencil. The ear, eye and } \\
\text { mouth on the other hand are } \\
\text { drawn in a more realistic } \\
\text { style with shading and } \\
\text { perspective. }\end{array}$ & $\begin{array}{l}\text { We're a video production company so the heart is } \\
\text { that we love what we do...we are quite } \\
\text { multisensory, it's about us listening to people....the } \\
\text { eye is there because it's very visual as well. It's } \\
\text { about the people and their stories that we film, } \\
\text { everybody has a story and it's up to us to get those } \\
\text { stories out of people. }\end{array}$ & $\begin{array}{l}\text { Relationships/ } \\
\text { Embodied/ } \\
\text { Storytelling }\end{array}$ \\
\hline $\begin{array}{l}\text { Happy and sad faces } \\
\text { interlinking (evokes } \\
\text { theatre symbol } \\
\text { comedy/tragedy masks) } \\
\text { Leadership development } \\
\text { entrepreneur - male }\end{array}$ & $\begin{array}{l}\text { The two faces take up the entire } \\
\text { page. The viewer is drawn to the } \\
\text { emotion conveyed through the } \\
\text { mouths one is happy (upward } \\
\text { arch) the other is sad } \\
\text { (downward arch). }\end{array}$ & $\begin{array}{l}\text { The image is simply } \\
\text { rendered with two } \\
\text { overlapping circles with } \\
\text { eyes and mouths. The circles } \\
\text { share one eye in the middle. }\end{array}$ & $\begin{array}{l}\text { We work with people and we try to encourage them } \\
\text { to make their lives better by creating an } \\
\text { environment in which they can learn, therefore } \\
\text { moving from one state of perplexity if you like, to } \\
\text { one state of, happiness would be the wrong word } \\
\text { but enlightenment. }\end{array}$ & $\begin{array}{l}\text { Relationships/ } \\
\text { Comedy/tragedy } \\
\text { masks } \\
\text { Theatre }\end{array}$ \\
\hline $\begin{array}{l}\text { The word 'clients' on a } \\
\text { stage with the lights } \\
\text { shining on and } \\
\text { highlighting the word } \\
\text { Public relations } \\
\text { entrepreneur - male }\end{array}$ & $\begin{array}{l}\text { The most prominent part of the } \\
\text { image is the word 'clients' } \\
\text { which is drawn to encompass } \\
\text { the whole of the stage, all the } \\
\text { other elements in the image } \\
\text { orientate towards this element. }\end{array}$ & $\begin{array}{l}\text { The word clients in drawn in } \\
\text { a three dimensional shape } \\
\text { using shading to give the } \\
\text { sense that the letters are } \\
\text { almost standing on the stage. }\end{array}$ & $\begin{array}{l}\text { It's a stylised stage our clients are very much at } \\
\text { centre stage our role is the illumination I } \\
\text { suppose...we are not actually the story...I see } \\
\text { myself as the conductor, sometimes the composer. }\end{array}$ & $\begin{array}{r}\text { Relationships/ } \\
\text { Theatre/ } \\
\text { Orchestra }\end{array}$ \\
\hline
\end{tabular}

